\title{
"May Their Limbs Melt, Just as This Lead Shall Melt...": Sympathetic Magic and Similia Similibus Formulae in Greek and Latin Curse Tablets (Part 1)*
}

\author{
Juraj Franek \\ Czech Academy of Sciences, Centre for Classical Studies at the Institute of Philosophy \\ Na Florenci 1420/3, 11000 Prague 1, Czech Republic; franek@ics.cas.cz \\ Masaryk University, Department of Classical Studies \\ Arna Nováka 1/1, 60200 Brno, Czech Republic; j.franek@mail.muni.cz
}

\section{Daniela Urbanová}

Masaryk University, Department of Classical Studies

Arna Nováka 1/1, 60200 Brno, Czech Republic; urbanova@phil.muni.cz

For citation: Juraj Franek, Daniela Urbanová. "May Their Limbs Melt, Just as This Lead Shall Melt...”: Sympathetic Magic and Similia Similibus Formulae in Greek and Latin Curse Tablets (Part 1). Philologia Classica 2019, 14(1), 27-55. https://doi.org/10.21638/11701/spbu20.2019.103

In this contribution, we present a representative corpus of similia similibus formulae attested in ancient Greek and Latin curse tablets or defixiones. The simile formulae, attested in about 80 tablets in widely differing states of preservation and legibility, are introduced in the context of sympathetic magic and, in contradistinction to literary similes, as performative utterances that are based on a persuasive analogy. This analogy operates in the general form of "just as $\mathrm{X}$ possesses property $\mathrm{P}$, so let also $\mathrm{Y}$ possess property $\mathrm{P}$ ", in which $\mathrm{Y}$ is the target or victim of the curse, while $\mathrm{X}$ and $\mathrm{P}$ are variables that change in accordance with the intended results. We provide a provisional taxonomy of simile formulae, offer new readings and interpretations of some defixiones, and compare Greek and Latin documents. Due to its length, the paper has been divided into two parts. In the first part, presented here, we focus on comparata that reference the materiality of the tablet itself and comparata referencing corpses or ghosts of the dead. The remaining comparata, namely animals, historiolae and rituals, aversus formulae and unusual orientations of the script, "names", and drawings, will be presented in a follow-up paper, to be published in the next issue of Philologia Classica.

Keywords: curse tablets, defixiones, ancient magic, sympathetic magic, Greek and Latin epigraphy, similia similibus, simile formula, materiality, ghosts in antiquity.

* The authors would like to express their gratitude to the two anonymous reviewers for the very helpful comments and suggestions they provided and to Elena Zheltova, Editor-in Chief of Philologia Classica, for her extraordinarily constructive attitude in accommodating a prohibitively long original draft by allowing us to publish it in two parts. We also wish to thank Andrea Barta, Alexey Belousov, and Giovanna Rocca, who kindly shared their hitherto unpublished research with us. This study is a result of the project GA ČR 19-02741S "The Transmission and Transformation of Ideas in Hellenism, Early Judaism, and Early Christianity" funded by the Czech Science Foundation.

(C) St. Petersburg State University, 2019 


\section{Introduction}

Curse tablets provide an important piece of epigraphical evidence for ritual practices based on sympathetic magic in the ancient Mediterranean world. In what follows, we aim to provide a representative overview and provisional taxonomy for the use of simile formulae in Greek and Latin defixiones, attested in about 80 tablets (in widely differing states of preservation and legibility) spanning more than a millennium in time, from the 5 th cent. BCE up to the 5th cent. CE, and attested in every corner of the oikumene, from Aquae Sulis (modern Bath) in Britannia and Hadrumetum in Africa to Pontic Olbia in Ukraine and Oxyrrhynchus in Egypt. The conclusions will briefly summarize the similarities and differences between Greek and Latin documents. Defixiones or curse tablets have been minimally defined as "inscribed pieces of lead, usually in the form of small, thin sheets, intended to influence, by supernatural means, the actions or the welfare of persons or animals against their will". To date, over 1,600 Greek and Latin defixiones have been published, with new findings and known but previously unpublished texts increasing the number every year. Approximately one third are written in Latin and two thirds in Greek; occasionally, we also find bilingual curses. Greek tablets start appearing in our records from the 5th cent. BCE, often in the form of simple lists of names, while the earliest Latin curses are dated to the 2 nd cent. BCE. ${ }^{2}$ Both disappear from the archaeological record in the 5th cent. CE. In many cases, we are not able to pinpoint the context, the background, or the author's precise desired effects, and these curses are classified as non-specific. ${ }^{3}$ Those curses in which the motivations and desires of the practitioners are more transparent have been traditionally classified as defixiones iudiciariae (legal curses), agonisticae (agonistic curses), amatoriae (love spells), and in fures (curses against thieves). ${ }^{4}$

Legal curses were usually aimed at an opponent in court and strived to eliminate his or her ability to think or speak during the process, resulting in the cursing party winning the lawsuit. Agonistic curses were aimed at rivals in circenses (gladiators, racers, charioteers, and racehorses) and were predominantly intended to limit their physical abilities and thus prevent them from winning in competition. The authors of these curses were their professional competitors or non-professionals betting on the teams. ${ }^{5}$ Love spells are associated with love and its desires. They were most often used to awaken a beloved person's affection in the case of unrequited love and sometimes included cases of rivalry in love, where the primary objective was to eliminate a rival by using a so-called "separation

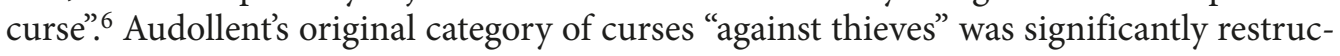

${ }^{1}$ Jordan 1985b, 205. While the vast majority of defixiones were written on lead, on occasion other materials were used as well; see note 18 below.

2 The cursing tradition had spread across the territory of ancient Italy among not only the Latins but also other nations of Ancient Italy. The fact that the earliest Latin curse tablets are attested only from the 2nd cent. BCE might be due to the randomness of the preserved archaeological record. It is likely that Latin curse practices (just like the Oscan and Etruscan ones) started as early as the 4th-3rd cent. BCE; see Urbanová 2018, 209-212.

${ }^{3}$ Kropp 2008a; Kropp 2008b; Urbanová 2018, 18-20.

4 See Audollent 1904, lxxxiii and Kagarow 1929, 28. For a basic outline of modern taxonomies, cf. Faraone 1991, 3-5; Kropp 2008b, 179-189; Urbanová 2018, 18-30.

${ }^{5}$ For an overview, see Tremel 2004.

${ }^{6}$ See Faraone 1999 for an overview of the Greek material and Urbanová 2018, 175-177 for Latin documents. 
tured by Henk Versnel, ${ }^{7}$ a rethinking occasioned especially by new finds from Brittania in the 1970s and 1980s. Versnel introduced a new category of "prayers for justice", which was only loosely identifiable with the traditional defixiones in fures. These texts were mostly directed against thieves or people who had done some harm to the authors, i.e. against the (mostly) unknown culprits of robberies, with the desired effect of vengeance - the thief was to be punished and the stolen things returned.

The use of simile formulae in literature, from Homeric epics onwards, has been a constant focus of scholarly attention. ${ }^{8}$ Such use by Greek and Latin authors alike is both epistemic, which is to say that unknown or unfamiliar properties and relations encapsulated in a simile formula are explained via comparison with more familiar ones, and aesthetic, adding to the richness and beauty of the poetry. Thus, in Homer, Hector kills Patroclus

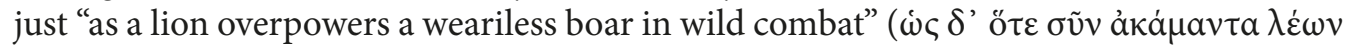

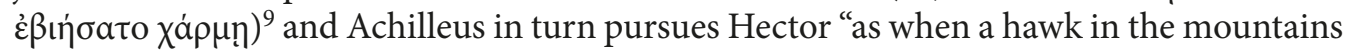
who moves lightest of things flying $\mid$ makes his effortless swoop for a trembling dove"

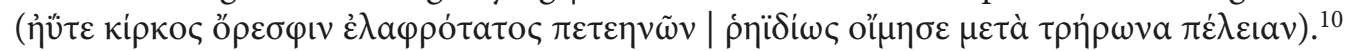
The use of simile formulae in defixiones and other epigraphic documents pertaining to magical tradition is a much less researched topic. The most important difference for the simile formulae encountered in defixiones (as compared to the literary functions) lies in their performative force. The given similarity is not simply observed and stated - it is "weaponized" since the writers of the ancient curses wished to transfer, by magical means, the properties of certain objects and actions onto their adversaries or objects of desire.

Thus, the use of simile formulae in Greek and Latin defixiones may be viewed as a token of "sympathetic" or, more precisely, "homeopathic" magic, the principles of which were established over a century ago by the pioneers of comparative anthropology Edward Burnett Tylor (1832-1917) ${ }^{11}$ and James George Frazer (1854-1941). ${ }^{12}$ While their general views on magic as a primitive stage of human thought that later evolved into "religion" and eventually reached maturity in science have been long abandoned, ${ }^{13}$ the principle of homeopathic magic or the "law of similarity"14 has been salvaged by the cognitive turn in so-

7 See especially Versnel 1991, 60-106 and Versnel 2010, 275-356, who defined these as prayers addressed to gods who were to punish a person or people (usually unknown) who had caused some harm to the tablet's author (e.g. through theft, fraud, denigration, false accusation). Frequently, compensation for damages was also demanded (e.g. the thief would be compelled to return the stolen things or plead guilty in public). Despite these important observations, the category of "prayers for justice" has been criticized by Martin Dreher, who proposed a new category: defixiones criminales; cf. Dreher 2010, 301-335 and Dreher 2012, 29-30. For a comparison of these two competing views, see Urbanová 2014, 1070-1081 and Urbanová 2018, 24-30, 180-197 and especially 420-425. This analysis of the desired results in both cases shows that these are to a great extent similar. Both curses and prayers for justice use the same sort of means to afflict the victim or the culprit; furthermore, the authors of prayers for justice frequently invent significantly more cruel ways to afflict the victims than the authors of other types of curses (Urbanová 2018, 24-30, 180-197).

${ }^{8}$ Cf. especially Scott 1974 and Scott 2009; for a comparative perspective, see Ready 2018.

9 Hom. Il. 16, 823.

10 Hom. Il. 22, 139-140.

11 Tylor 1871, 104-106 spoke about the principle of an "Association of Ideas" and a "connexion [...] of mere analogy or symbolism".

12 Tylor 1871, 101-144; Frazer 1990 12-48.

13 Pyysiäinen 2004, 90-112; Yelle 2001, 634.

14 Frazer 1990, 12-13: "Perhaps the most familiar application of the principle that like produces like is the attempt which has been made by many peoples in many ages to injure or destroy an enemy by injuring or destroying an image of him, in the belief that, just as the image suffers, so does the man, and that when it perishes he must die." 
cial sciences and humanities. ${ }^{15}$ Simile formulae, just as ancient "voodoo-dolls" or kolossoi, employed persuasive analogies, which, unlike empirical analogies, do not anticipate future events by virtue of parallel events observed. On the contrary, they try to actively influence future events according to a predesigned model. In terms of cursing rituals, persuasive analogies are intended to transfer the desirable features of one object to another, with the objects concerned possessing both similarities and differences. ${ }^{16}$ If the literary use of a simile follows the general structure of " $\mathrm{X}$ is/will be like $\mathrm{Y}$ ", the performative variant follows the form of "just like $\mathrm{X}$ has the property $\mathrm{P}$, so let $\mathrm{Y}$ also have the same property $\mathrm{P}$ ".

In Greek, this performative function is realized on the syntactic level as a complex sentence introduced by $\tilde{\sigma} \sigma(\pi \varepsilon \rho)+$ comparatum + indicative followed by a oú $\tau \omega(\varsigma)$ clause containing the target of the curse + future indicative, dynamic infinitive, subjunctive, or optative. In Latin, comparative clauses with quomodo - sic or ut/ita - sic are used with a wish-formula containing the volitive (prohibitive) subjunctive in the main clause, which is unattested in literary texts and very rare in other epigraphic documents. ${ }^{17}$ In what follows, we offer an overview of the most commonly found comparata in extant Greek and Latin defixiones containing one or several simile formulae. These are arranged into seven categories depending on whether the persuasive analogy makes use of (I) the materiality of the tablet, location, and manipulation; (II) human corpses and ghosts of the dead; (III) animals; (IV) historiolae and rituals; (V) aversus formulae and unusual orientations of the script; (VI) "names"; or (VII) drawings on the tablets. Due to the prohibitive length of the original paper, it was necessary to divide it into two parts. Here, we cover categories (I) and (II); in the second part of the paper, to be published in the subsequent volume of Philologia Classica, we will focus on the remaining categories and present the final conclusions.

\section{Materiality, location, and manipulation}

In the following section, we discuss simile formulae in which the persuasive analogy refers to either the material of the curse tablet itself, its location, or any manipulation that the tablet as a whole has been subject to. In both Greek and Latin magical tradition, the most numerous comparatum in simile formulae on defixiones in this category is - quite unsurprisingly - lead, the metal of choice for ancient curses by a very large margin. ${ }^{18}$ Lead was used as a comparatum as early as the 5th cent. BCE (to be discussed below as item (5) in our corpus), but the most representative examples are provided by three tablets with curses in legal contexts from Attika dated to the 4 th and 3rd cent. BCE. ${ }^{19}$

15 Nemeroff - Rozin 2000; Sørensen 2007.

16 See, e.g., Tambiah 1978, 275; Faraone 1991, 8; Kropp 2008b, 175-177.

17 For a detailed linguistic study of the quomodo ... sic clauses in Vulgar Latin, see Urbanová 2016; for simile formulae on defixiones, see Kropp 2008b, 175-177 and Kropp 2010, 370.

18 A clear majority (around 95\%) of extant curses are on lead, yet its use was not obligatory or exclusive. There are instances in the PGM of instructions requiring papyrus or lead (cf., e.g., PGM V, 305) and the metal's superior durability (compared to papyrus or wax) certainly skewers our perspective on how much of which materials were used. See further especially Faraone 1991, 7 for some evidence of other media than lead (such as wax) and Kropp 2008b, 329 for Latin curses.

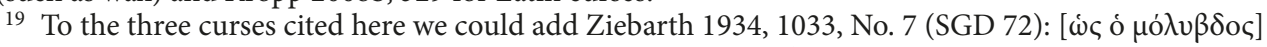

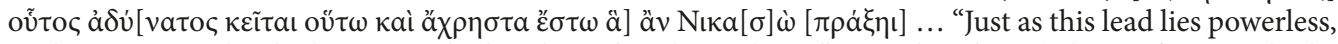
in the same way, let the business which Nikasō does be useless..." (transl. Eidinow), but unfortunately the tablet is too damaged to be sure that the comparatum was indeed lead. 
(1) DTA 105 (TheDeMa 976)

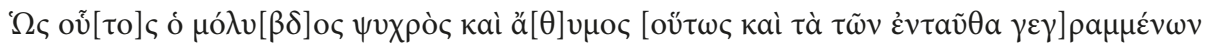

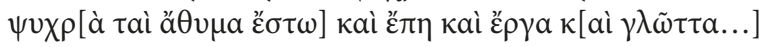

"Just as this lead is cold and spiritless, in the same way also, let the words and deeds and tongue of those inscribed here be cold and spiritless..." (transl. Eidinow)

(2) DTA 106 (TheDeMa 977)

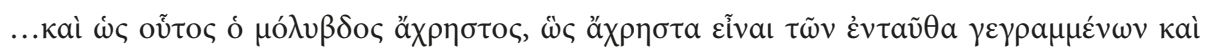

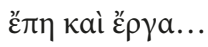

"And just as this lead is useless, in the same way may the words and deeds of those inscribed here be useless..." (transl. Eidinow)

(3) DTA 107 (TheDeMa 120)

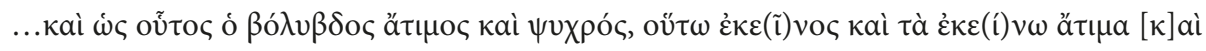

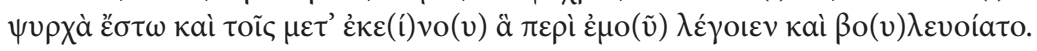

"And just as this lead is worthless and cold, so may that man and his doings be worthless and cold and for those on his side, whatever they say or plan about me." (transl. Eidinow)

In all three instances, the material's physical characteristics and relative uselessness in the system of economic exchange relative to "precious" metals, such as gold or silver, are alluded to and transferred to the targets of the curses. Lead is "cold" ( $\psi v x \rho o ́ \varsigma)$, an observation readily made by anyone coming into contact with it, and the cursed persons should also become "cold", i.e. incapacitated and rigid, possibly dead, as well as "spiritless"

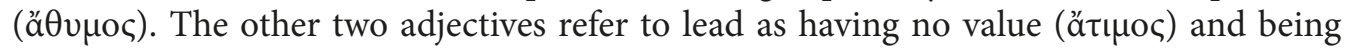

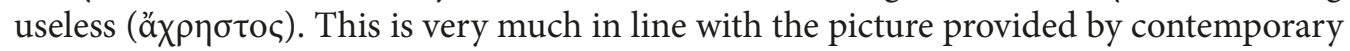
literature, where lead is a prime example of a low-quality metal, inferior in strength to iron and incomparable in monetary value to precious metals. ${ }^{20}$ In both (1) and (2), the words and deeds of the targets of the curse should become "worthless" and "useless" (most likely in the context of a court case, referring to the inability to speak before court), ${ }^{21}$ in

20 Cf. Thgn. 417-418, 1104a-1106, 1164g-1064h; Hdt. 3, 56; Ar. Nub. 912-913; for Roman authors, see, e.g., Ov. Met. 1, 463-473.

${ }_{21}$ The reference to the tongue and the transfer of attributes from lead to the tongue, only conjectured

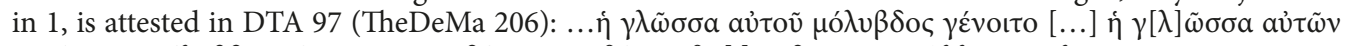

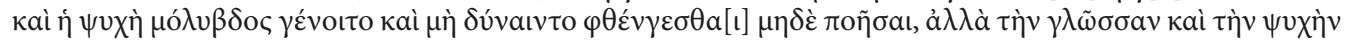

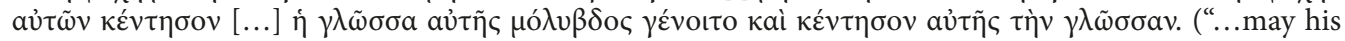
tongue become lead [...] may their tongues and souls become lead and may they be unable to speak or act; but rather stab their tongue [...] may her tongue become lead; and stab her tongue", transl. Gager). Compare also LCT 70 (DFX 5.1.2/1): ... ut Fronto fiat mutus, cum accesser(it) consularem, ut sit mutus neque pos(sit) loqui, neque quicquam agree... "...may he become mute when he approaches the legate, may he be mute and unable to speak or do anything...”; LCT 71 (DFX 5.1.2/2): (Do i)nimicos Sexti, ut sic non possint (cont-) ra Sextum venire nec agere quicq(uam) possint... ut sic (sint) vani et $m(u t i)$... ("[I commend] the enemies of Sextus, so that they will not be able to come out or take any actions against Sextus... so that they will be idle and mute..."); LCT 136 (DFX 11.1.1/32): ...(alligo linguas)... medias, extremas, novissimas... colligo, ligo linguas... medias, extremas, novissimas, ne quid respondere (possint), facias vanos... ( "... [I bind their tongues] ... in the middle, back, and front... I tie, bind up [their] tongues in the middle, back, and front, [so

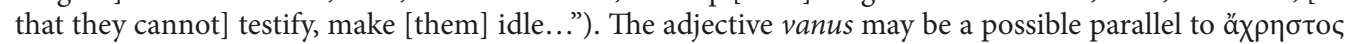
in (2). 
(3) it is also the cursed individuals themselves that should become "cold and useless" (i.e. paralysed or even dead).

It remains unknown whether the use of lead as the medium for the curse tablets was due to its availability or whether some magical properties attributed to lead by ancient Greeks and Romans played a role. ${ }^{22}$ Despite the fact that a handful of scholars have argued for the importance of magical and symbolic factors in selecting lead as the material of choice for curse tablets, ${ }^{23}$ the communis opinio suggests that the primary reason for the use of lead was its easy availability as a by-product of silver mining. The association of lead with magical powers due to its physical characteristics, such as its greyish dark colour, ${ }^{24}$ coldness, ${ }^{25}$ and durability (compared to wax or papyrus) is most likely only a secondary development, a by-product of using lead in production of defixiones for economic and pragmatic reasons (lead was commonly used for writing since it is cheap and easy to write on with a stylus made from harder metal). ${ }^{26}$

A tablet from Boiotia with widely divergent dating, ${ }^{27}$ addressed to one Theomnāstos (= att. Theomnēstos), contains no less than three simile formulae. While the first references the corpse or ghost of Theomnēstos (see (24)), the other two mention lead. For the magical transfer of essence, they do not use the metal's physical properties, as was the case in (1), (2) and (3), but rather its location. ${ }^{28}$ The curse is directed against Zōilos, who was at the time seeing a girl named Antheira. In a fashion typical for separation spells, the curse is aimed at destroying the relationship and securing the girl's love for the author of the curse by eliminating the amorous rival. The lead tablet is deposited in a "location se-

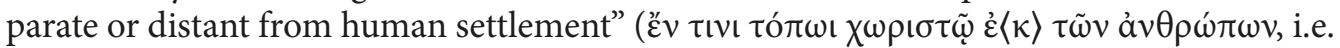
in a grave) - and just so should Zōilos be separated or grow distant from Antheira. The

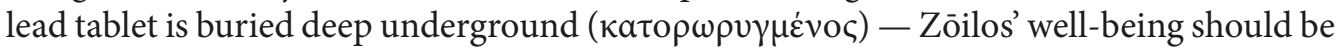
equally "buried down" and destroyed.

(4) Curbera 2017, No. 2 (Ziebarth 1934, No. 23, TheDeMa 185)

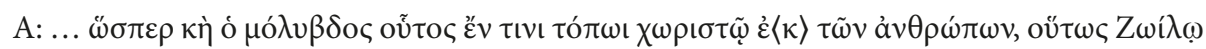

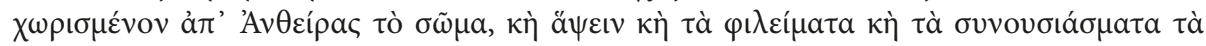

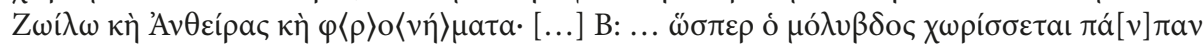

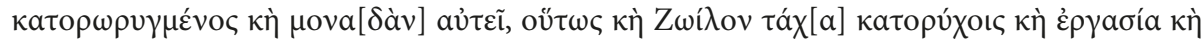

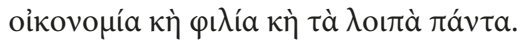

22 Forbes 1950, 177-178.

${ }^{23}$ Kagarow 1929, 9-10.

24 Ov. Fast. 2, 275: tunc cantata ligat cum fusco licia plumbo.

25 Plut. De sera 30, 567b10-c1.

${ }^{26}$ See already Wünsch 1897, iii: "Sed primis licet temporibus in his lamminis non tam ex peculiari quadam superstitione quam ex facili et commodo eius metalli in scribendo usu scripserunt antiqui, ubi primum adhibebant hoc metallum ad artes magicas, accessit superstitio, quae plumbum efficacissimum inter omnia esse docebat, quo dii inferi allicerentur." Gager 1992, 3-4 essentially agrees with Wünsch that the primary reason for choosing lead was its availability and that the connection with magic properties was a later, secondary development; cf. also Graf 1996, 119-120; Baratta 2012, 24; Kropp 2015, 78-80. Regarding various uses of lead in antiquity, see Baratta 2013, 283-284 (with further literature); for the connection of lead to Saturn (stella nocens), see Baratta 2012, 24-25.

27 Faraone 1991, 13 dated it to the 3rd-2nd cent. BCE; Gager 1992, 88, No. 20 and López Jimeno 2001, 145, No. 300 both to the 2nd-3rd century CE; Bravo 1987, 202, however, again to the 3rd cent. BCE; Curbera 2017, 142 again to the 3 rd-2nd cent. BCE.

${ }^{28}$ Unfortunately, we have no indication of the place of origin, but the context makes it virtually certain that it was deposited in a grave. 
“....and just as this lead (is) in some place separated from humans, so may Zoilos' body be separated from Anthera - and touch and kisses and the intercourse of Zoilos and Anthera, and their thoughts ... [...] ... just as the lead is completely separated, buried and isolated here, so too bury Zoilos quickly, and his activity, dealings, love and all the rest." (transl. Curbera)

The oldest Greek tablet with a performative simile explicitly mentioning lead is an enigmatic opistographic tablet from Sicily (found near Gela) dated as early as the 5th cent. BCE. Side A seems to contain a record of a financial transaction in which Apellis, the presumed author of the curse on side B, makes an appearance as the guarantor of the transaction and the money deposit connected with it. ${ }^{29}$ On side B, Apellis seems to be reusing the lead tablet as a means to a new end, namely to fashion a curse that is intended to benefit

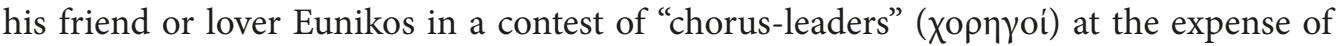
other participants whose names are listed on the tablet. We find the simile formula at the very end of the curse.

(5) Wilson 2007 (Jordan 2007, SEG 57:905, TheDeMa 250) ${ }^{30}$

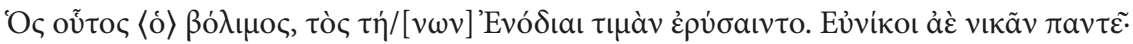

"Just as this lead (sc. effectively drew the tima of the guarantee), so may the Enodiai draw out the tima of those men ( $s c$. the rival khoragoi and their supporters listed in the tablet by

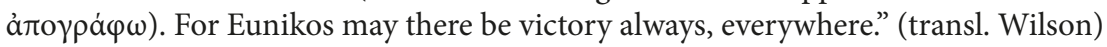

There have been many interpretations of this puzzling tablet. Dubois translated the simile as "Que tant de tablettes de plomb, que le prix du plomb (qui est considérable) sauvegardent à tout jamais et par tout la victoire pour Eunikos ...."31 but this makes little sense, since the value or price of lead ("prix du plomb") was emphatically not high ("considérable") - as has been shown above, lead was rather cheap and easy to obtain. Gager proposed the translation "As this lead tablet (is inscribed) so let ... preserve victory for Eunikos everywhere...", but this does not command much confidence either. ${ }^{32}$ According to the most recent interpretation by Peter Wilson, ${ }^{33}$ which we consider the best available, just as the lead tablet had already successfully "guaranteed" the financial transaction in its first use (a record of which is preserved on side A), it should be just as efficient in securing the success of Eunikos by eliminating ("drawing out the honour or prestige") his opponents in the competition of the chorus-leaders via a timely intervention by Enodiai, in plural an otherwise unattested name but in its singular form used to refer to Hecate Wilson even floated the suggestion that it could be a collective name for the goddesses Demeter and Kore.

In Latin curses, lead appears as a comparatum in six tablets from Germania, Gallia, and Pannonia (dated to the 1st and 2nd cent. CE), of which four are readily interpretable.

${ }^{29}$ See Jordan 2007, 337-342 for a detailed analysis.

30 The tablet was first published by Miller 1973. The cited SEG entry is a new autopsy by Jordan 2007,

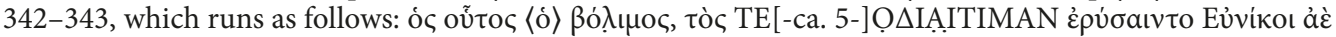
$\nu เ \kappa \tilde{\alpha} \nu \pi \alpha \nu \tau \tilde{\varepsilon}$.We print the reading and translation by Wilson 2007, 375-377, which is itself based on Jordan's text.

31 Dubois 1989, 158-159, No. 134.

32 Gager 1992, 76-77, No. 17.

33 Wilson 2007, 375-377. 
The first from Carnuntum is a unique prayer for justice, containing the typical aggressive features of curses (defigo Eudemum) incorporated into a prayer for justice that targets the suspected thief, Eudemus, by name. Found in an amphitheatre (possibly deposited in a "Leichenkammer" underneath it) ${ }^{34}$ and dated to the 2 nd cent. CE, the writer requests from the gods of the underworld the punishment of a certain Eudemus, a man who stole his vessel.

(6) Egger 1962 (DFX 8.3/1, LCT 239, TheDeMa 265) $)^{35}$

Defigo Eudem(um) nec(et)i(s) eum pes(s)imo leto, ad inf(er)os d(uca)tis eundem recol(l)igatis $M($ anibu)s ministeria infernorum (d)eu(m). (Quom)do i(lle) plu(m)bus po(n)dus $h(a)$ bet sic et $(E)$ ud(e)mus $h(a)$ beat $v(o)$ s iratos, inter la $(r)$ vas... ia $(m)$ hostiat quam celeris $(s)$ im(e).

"I curse Eudemus; kill him by the worst death, lead him to the underworld and bind him with ghosts, you servants of the infernal gods. Just like this lead has weight, may Eudemus feel your [heavy] anger, may he enter among the ghosts of the dead as quickly as possible." 36

The lead tablet is described here as "heavy" (plumbus pondus habet), which is a quality alluded to indirectly by other two tablets as well. Both seem to convey the "heaviness" of lead using verbs of "falling" or "sinking" (decadere, subsistere) into the depths. The term ira with the meaning of "anger/wrath of gods" is well attested from Latin defixiones. ${ }^{37}$ The term pondus may be understood also metaphorically — just the curse has "weight" (i.e. importance) among the gods, so may they be angered at Eudemus and kill him.

(7) Marichal 1981 (DFX 4.4.1/1, LCT 226, TheDeMa 735)

Quomodo hoc plumbu(m) non paret (= apparet?) et decadet ${ }^{38}$ sic decadat aetas, membra, vita, bos, grano $(m), \operatorname{mer}(x)$ eoru $(m)$, qui mihi dolum malu $(m)$ fecerunt...

"Just as this lead is not visible and sinks to the bottom, so may the youth, limbs, life, livestock, grain, and trades of those who deceived me badly also fall into decay..."

${ }^{34}$ Cf. Egger 1962, 81 and Kropp 2004, 85.

${ }^{35}$ Most of the defixiones texts have been damaged to a greater or lesser extent, primarily due to age, corrosion, or mechanical damage caused by manipulation with the tablets, either already in antiquity (e.g. by the tablet being folded and pierced with nails) or during excavations. Moreover, the Latin texts contain numerous deviations from the classical norm caused by various factors (e.g. local specifics, diachronic developments, the author's literacy). For the purpose of this article, we have included emended Latin texts that do not necessarily follow the Leiden Conventions since rigorous adherence to epigraphical modus operandi would make the texts less intelligible to the general reader (cf. also the Lesetext of Kropp 2008). Round brackets are used to denote editorial interventions, such as emendations, restorations, lectiones variae, and other peculiarities.

36 Unless indicated otherwise, the translations are our own.

37 See, e.g., the curse from Bergenz, DFX 7.1/2 (LCT 104), most likely written in the context of a rivalry in love, which is terminated by the words Ira dei. A tablet from Mainz (DTM 5, LCT 85) reads Bone sancte Atthis Tyranne, adsi(s), advenias Liberali iratus. ("Good, holy Att(h)is, Lord, help [me?], come to Liberalis in anger.") As Kropp 2004, 88 suggested, the author of the curse could have considered the anger of the gods as an appropriate punishment for the morally reprehensible behaviour by the culprits which is denounced in the prayers for justice.

${ }^{38}$ Cf. Marichal 1981, 41-43 and Lejeune 1981, 51-52, decadet = class. Lat. decidit. 
....sic comdi (=quomodo) plumbum subsidet, sic Sintonem et Martialem Sint(onis) et adiutorium Sintonis et quisquis contra Rubrium fr(atre) $m^{39}$ et me Quartionem, si qui(s) contravenerit, Sintonem et adiutorium eius Sintonis defero ad infero(s). Sic nusquam contra nos (inve-) nisse respon(sio)nis, cum loquantur inimici. Sic (d)esumat non parentem ${ }^{40}$ tanquam infero(s).

"Just as the lead sinks [to the bottom], so I drive down to the gods of the underworld Sinto and Martialis, [the son/slave] of Sinto, and his assistant and whomever [is] against my brother Rubrius and me, Quartio, if anyone comes out against [us], Sinto and the assistant of this Sinto. In this way, [he/they, i.e. our enemies] can never compose a response against us when our enemies speak out. In this way, may [this lead tablet] afflict? [Sinto] absent [at court?] just like [as if he was in?] the underworld."

In the case of (7), a prayer for justice dated to the 1st cent. CE, it is important to note that the tablet was not found in a grave but in a well in Montfo (modern Magalas, southern France). The tablet was supposed to remain invisible to mortals' eyes (non apparet) and its descent into the depths (decadet) was to be mirrored by the gradual decay of the target's life, livestock, and grain as an appropriate punishment for the dolum malum caused to the tablet's author by the suspects named on the tablet. Simile (8), a legal curse found in a grave in Kreuznach and dated to the 2nd cent. CE, also contains a persuasive analogy based on the "fall" of the lead tablet. It "sinks to the bottom" (subsidet) and similarly Sinto and Martialis - and, pre-emptively, anyone wishing to do harm to Rubrius and Quartio, the authors or commissioners of the curse - should be thrown into the underworld (deferre ad inferos). Several Latin curse tablets from the Sanctuary of Mater Magna in Mogontiacum (modern Mainz), dated to the 1st-2nd cent. CE, showcase simile formulae containing implicit references to special manipulation of the lead tablets - more specifically, throwing them into fire or burning them (at least symbolically?). Consider, for instance, the best-preserved example of a prayer for justice aimed at punishments for the culprits.

\section{(9) DTM 11 (LCT 236, TheDeMa 754) ${ }^{41}$}

Placida et Sacra, filia eius: sic illorum membra liquescan(t) quatmodum hoc plumbum liquescet ut eoru $(m)$ exsitum sit.

"Placida and Sacra, her daughter: may their limbs melt, just as this lead shall melt, so that it shall be their death." (transl. Blänsdorf)

Jürgen Blänsdorf, the editor of the Mainz tablets, argued that the curses were eventually thrown into the sanctuary's sacrificial fire where they melted down (the fact that they have been preserved is, according to him, due to "chance"). ${ }^{42}$ Two other tablets from the

39 The text is slightly corrupted; we are following the reading of DFX 5.1.4/5 and CIL XIII 2, 1, 7554.

40 We follow Wünsch, who reads desumat (sc. plumbum Sintonem) and then non parentem (sc. ita ut in iudicio non appareat). The tablet may be unfinished; the writer may have run out of space. Perhaps we could surmise something akin to tanquam esset apud inferos.

${ }^{41}$ An almost identical formula is found on the tablet DTM 12, a continuation of this one. Moreover, DTM 12 includes a list of body parts that should melt away: sic ... s siccum QUANMI qu(omo)di hoc liquescet se (... sic co)llum membra, me(du)lla, peculium d(e)l(i)ques $($ ca)nt eoru $(m)$ "so ... dry ... just as this is to melt, so may his neck, limbs, strength, savings melt away" (transl. Blänsdorf).

42 Blänsdorf 2012, 124. 
same archaeological find reference "melting" (deliquescat) or "flowing" (defluit) in close syntactic proximity to lead; ${ }^{43}$ unfortunately, they are too damaged to contribute much to our knowledge of this peculiar practice. Further support for this interpretation may be found in the following hitherto unpublished Sicilian Greek defixio dated to the 1st-2nd cent. CE, which also references "melting" of the lead.

(10) Rocca - Bettarini - Bevilacqua, in print

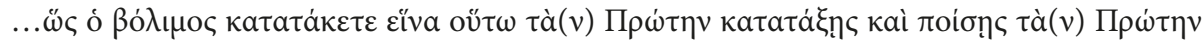

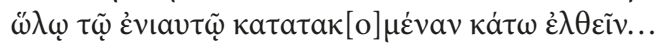

"Just like the lead melts away, so let also Protē melt away and make it so that Protē, after melting away for an entire year, will descend [into the underworld?]."

Our last example from Mainz, dated to the 1st-2nd cent. CE and written with the apparent desire to do away with a rival in love, does not mention lead (plumbum) explicitly, but rather denotes the tablet with the term haec carta.

(11) DTM 15 (DFX 5.1.5/4, LCT 91, TheDeMa 753)

...(P)rima Narcissi aga(t) como haec carta nuncquam florescet, sic illa nuncquam quicquam florescat. ${ }^{44}$

"May this befall Prima, the lover of Narcissus: just as this tablet shall never bloom, so she shall never bloom in any way." ${ }^{4}$

There can be no doubt that haec carta is the lead tablet itself. It is quite common for curse authors to call their creations "letters"; 46 furthermore, the nature of the simile itself confirms this identification - indeed, the one thing that a piece of cold, dark lead cannot do is "bloom". A Latin defixio from Fontanaccia, found in a grave and dated to the 2nd-3rd cent. CE, combines a mention of a "letter" (charta), as seen in the previous example (11), with an implied reference to downward movement (falling, descent), as seen in (7) and (8).

(12) Stanco 2003 (TheDeMa 1091) ${ }^{47}$

$Q(u)$ omodo h(a)ec charta coelis abeati (=abeat) in deo Adonine (= Adonide) cito iacit, silet, lang(u)et sic(c)ata, sic Quintus, Agrippini s(ervus) uter saltuensis (= salutarius?), languiat aigrotis ...

43 These are LCT 235 (DTM 7, TheDeMa 878): ...quomodi (et) ho...sucus defluit e...hoc plumbum... “...just as liquid flows out of ... this lead [will melt?]..." and LCT 89 (DTM 10, TheDeMa 124): ...diliquescant quatmmodi hoc diliquescet... "...may they melt away just as this [piece of lead] will melt away...”.

${ }^{44}$ For this interpretation, see Blänsdorf 2007-2008, 6. The text is written counterclockwise because of the magic use of compounds of the verb verto.

${ }^{45}$ For the simile formula, see also Urbanová 2016, 333-339.

46 See, e.g., Curbera - Papakonstantinou 2018, No. 4 (TheDeMa 118, DTA 103): "E $\rho \mu[\eta \iota]$ кaì

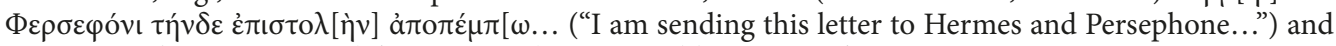
its Latin analogue LCT 306 (TheDeMa 713) carta qua(e) Mercurio donatur.

47 The reading is ours. Stanco reads: Ligo modo modo hec charta coelis abeat $<i>$, in deo Adonine cito iacit, silet, langet sicata, sic Quintus, Agrippini s(ervus) uter saltuensis, languiat aigrotis; ex omologi(s) feri igni(s), n(atus) ann(is) IL, devincit; non seion fortior et sic moriatur. 
"As this letter quickly descends from the upper regions down to the god Adonis [and there] lies mute, enfeebled, and drained dry, so let Quintus, servant of Agrippinus, uter salutensis, ${ }^{48}$ be enfeebled and sick..."

Another interesting Latin tablet containing a simile formula that references a "letter" (epistula, i.e. the tablet itself) has been found in Kempraten (Switzerland) in the precinct of a Gallo-Roman sanctuary. It is dated to the 2 nd to 3 rd cent. CE and contains a prayer for justice addressed to Magna Mater. ${ }^{49}$ The text is partly damaged, but the use of the tablet as the comparatum of the simile formula is manifest.

(13) Frei-Stolba et al. 2015 (TheDeMa 944)

...et qui lucer(n)am eius sustulit et qui conscius est et qui dolum malum facit, sic iace(at) +++ micto $^{50}$ que $(\mathrm{m})$ admodum haec epistula iacitura est.

“... and the one who stole the lamp and the one who knows about it and who deceived [me], let him/her lie [...] just like this letter will lie [here]."

The first part of the simile formula is difficult to interpret and the authors of the editio princeps believe that the sequence +++ micto is a substantivized participle of the verb meio ("to urinate"), from which they provisionally translate the simile formula as "...wer seine Lampe gestohlen hat und wer Mitwisser ist und wer arglistig täuscht, soll so im (zehnmal erzeugten?) Dreck liegen wie dieser Brief (im Dreck) liegen wird", but this seems quite unlikely to us as this reading presupposes that the tablet was deposited in a filthy place, which would hardly be appropriate for a solemn prayer to Magna Mater (there are no available parallels to such a deposition of a tablet). Despite the difficulties of interpretation, the tablet itself (epistula) is clearly used as a comparatum in the simile formula.

Two Greek curses written on other media than the virtually omnipresent lead seem, at least prima facie, to contain a simile formula with a "stone" as the comparatum. A closer look, however, reveals that the persuasive analogy is based on either manipulation of the material support for the curse (in the first example here, (14)) or the physical properties thereof (in the second example here, (15)). A unique curse written on papyrus (3rd-4th cent. CE, Oxyrrhynchus) mentions a "Hermes-stone of the mill" and targets the brain and heart of a certain Zètous. These are to be ground or turned just like the stones in the mill turn and grind - not only wheat, but the curse itself!

(14) SupplMag 56 (TheDeMa 291)

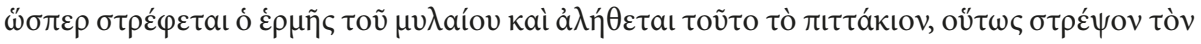

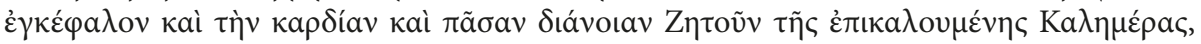

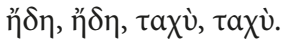

48 Stanco 2003, 138 translates this as: "nello stesso modo il servo di Agrippino Quinto, quello dei due addetto alla custodia del latifondo..." The reading uter is unclear; saltuensis could mean something akin to saltuarius, a "person employed in looking after an estate".

49 The text contains parallels to the Mainz tablets, such as the invocation of Mater Magna, as well as technical terms used in other prayers for justice (sustulit, dolum malum etc.); cf. also DTM 2, DTM 7, DFX 3.22/16, DFX 7.5/1.

${ }^{50}$ Geisser - Koch 2018, 298, n. 4 read in $x(!)$ micto. 
"As the Hermes-stone (?) of the mill turns and as this chit is ground, so turn the brain and the heart and the entire mind of Zetous also called Kalemera, now, now, quickly, quickly." (transl. Daniel - Maltomini)

Older discussions of the text have been marred by the reading "marrow" ( $\mu v \varepsilon \lambda$ oṽ) instead of "mill" ( $\mu \nu \lambda \alpha i$ ov), ${ }^{51}$ but the "sympathetic structure" and the simile formula have been recognized from the outset. ${ }^{52}$ Faraone's new interpretation, ${ }^{53}$ which identified o

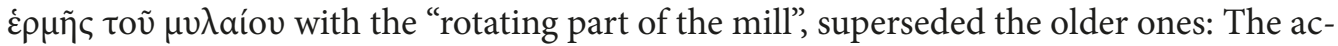
tion on the papyrus containing the spell (being ground or turned in the millstone) should be replicated in the brain and heart of Zètous. While usually considered a love charm ${ }^{54}$ in which the "turning of the brain and heart" should represent the spark of a new love interest in the curse's author, Faraone preferred to consider it an indeterminate curse, ${ }^{55}$ while Daniel and Maltomini have argued that the spell "was most likely used by a master against the slave Zetous-Kalemera, who was probably a fugitive or suspected of planning to run away". ${ }^{56} \mathrm{~A}$ far more straightforward simile featuring a stone is attested on an ostracon dated to the 4th-5th cent. CE found in Egyptian Thebes and a self-professed $\theta v \mu$ ка́ $\theta v \kappa \omega v$

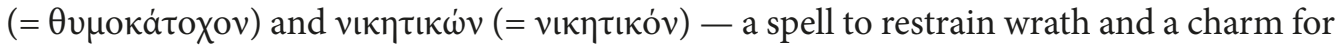
victory. ${ }^{57}$

(15) SupplMag 58 (TheDeMa 310)

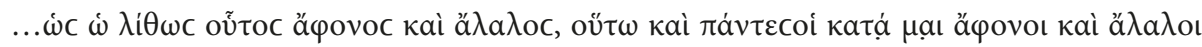

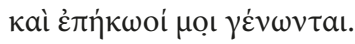

"...just as this stone is voiceless and speechless, so let also all who are opposed to me be voiceless and speechless and obedient to me." (transl. Daniel - Maltomini)

The "stone" in the simile formula is described as "voiceless" and "speechless" and the

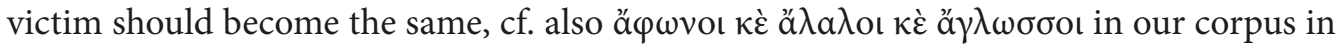
item (28). Daniel and Maltomini observed that the incipit of the curse was most likely mistakenly copied from the formulary, which moreover prescribed "stone" as the support material of choice. ${ }^{58}$ It is likely that the practitioner preferred to use ostrakon (which is, after all, much easier to write on than a stone) and the term $\dot{\omega} \lambda i \theta \omega c$ oũtoc then refers to the ostrakon itself, transferring the muteness of the ostrakon-"stone" to the victim. The magical analogy at work here is of the same kind as in the other cited cases featuring lead tablets - the only thing that changes is the material on which the curse is written. The last item in our first section is a famous prayer of justice from Aquae Sulis (Bath), found

${ }^{51}$ Editio princeps Turner 1976; see also Griffiths 1977, Giangrande 1978, and Gorissen 1980. Versnel

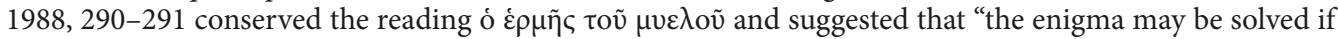
we take Hermes to be a little figurine", probably made of wax (cf. the Greek $\mu v \varepsilon \lambda$ ó, , "fat").

52 See, e.g., Giangrande 1978, 102.

53 Faraone 1988.

54 This is true for all authors mentioned in note 51 except Versnel.

55 Faraone 1988, 286.

56 Daniel - Maltomini 1992, 31.

57 Regarding these, see, e.g., Faraone 1999, 107-109.

58 Daniel - Maltomini 1992, 44-45. 
in 1880 and dated between the 2 nd and 4 th cent. CE, "the only instance in the Bath tablets of sympathetic magic" ${ }^{59}$

(16) TabSulis 4 (RIB 154, LCT 242, TheDeMa 150)

$\mathrm{Qu}($ i) mihi Vilbiam in(v)olavit sic liquat com(odo) aqua...

"May he who carried off Vilbia from me become as liquid as water..." (transl. RIB)

There have been various interpretations of vilbia: Audollent read man $(n) \operatorname{teliu}(m) ;{ }^{60}$ Tomlin in 1988 tentatively suggested either a copying error or fib(u)lam (a suggestion followed by Kropp); ${ }^{61}$ Russell argued that vilbia could be "a Brittonic term for some kind of pointed tool ... [whose] reflex may have survived in Welsh as Middle Welsh $g w l f$ ". ${ }^{62}$ It is also possible, however, that Vilbia is a female name and the prayer for justice targets a kidnapper or kidnappers. ${ }^{63}$ Whatever the case, the simile seems to destroy the target by literally "liquefying" him or her. Even under this straightforward interpretation, there is undoubtedly a deep-seated connection with the place of deposition of the tablet, which was sunk into water (Aquae Sulis, as the name suggests, were celebrated Roman baths). According to the OLD, liqueo means "to be in a molten or liquid state", 64 and we find it quite possible that in the mind of the author of the curse, the simile meant something akin to quomodo [hoc plumbum liquet] aqua (= in aquā) sic liquat [fur ille] qui mihi Vilbiam involavit ("Just as this lead tablet is submerged in water, so let the thief that stole my Vilbia be submerged in water, i.e. drown and die"). This interpretation would be very much in line with the fact that the physical interaction with the tablet reinforces the magical analogy: The author is not merely stating that the victim should become "liquefied" - rather, he or she performs the ritual action of submerging the tablet in water, which causes his or her adversaries to be symbolically submerged and drowned, since the tablet features a list of names (possible culprits of the crime). The logic of sympathetic magic in this case is no different than in the case of casting tablets into the fire to melt the victims or the case of placing curses written on a piece of papyrus between the millstones to "turn" or "grind" their brains and hearts.

\section{Dead human body, ghost of the dead}

Since tombs and graveyards are among the most common depositories for curse tablets, ${ }^{65}$ it is not surprising that human corpses and ghosts serve as comparata in several simile formulae. In these similes, it is sometimes very difficult to tell whether the writer was alluding to a dead body or a ghost, but the context and the specific qualities selected for magical transfer enable us to make an educated guess in most cases. ${ }^{66}$ We shall start

59 Tomlin 1988, 112. We include this tablet despite the simile formula being manifestly incomplete since there are interesting parallels with the Mainz tablets (see our (9) and DTM 10 and DTM 12).

60 Audollent 1904, 104.

61 Tomlin 1988, 112, No. 4; DFX 3.2/1.

62 Russell 2006, 366.

63 RIB 154, accepted by Tomlin — Hassall 1999, 384.

${ }^{64} \mathrm{OLD}$, s.v. liqueo.

${ }^{65}$ Graves are prevalent, but by no means exclusive, locations; see Urbanová 2018, 59.

66 The problem is complicated by the fact that creatures such as "revenants" were believed to be ghosts that returned to inhabit their former physical bodies, further blurring the difference between a corpse and 
with those instances where it can be reasonably assumed that the comparatum of the simile formula is a physical dead body. In these cases, the properties that are supposed to be magically transferred to the victims are predominantly of a restrictive and paralysing nature - the victims are to remain mute, immobile, and so on. In a tablet from Attica, dated to the 4 th cent. BCE, ${ }^{67}$ the corpse lying in the grave is described as "useless" or "in-

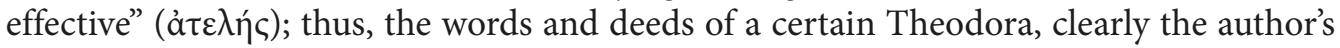
object of desire, should become the same with respect to Charias, probably her husband or lover (as well as other men, just to be sure).

(17) Jordan 1993 (DT 68, TheDeMa 104) ${ }^{68}$

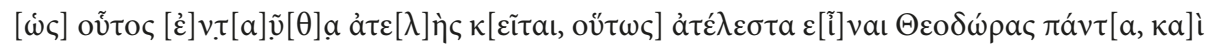

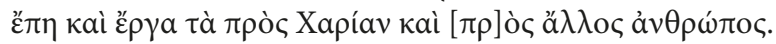

"Just as this (sc. dead person) lies here ateles, so let all things of Theodora, her words and deeds with respect to Charias and other men, be atelesta." (transl. Jordan)

In the context of love magic, the desire of the curse's author for the victim not to engage in any erotic activities (except with the author, of course) is an extremely common feature $^{69}$ and here it is reinforced by a simile formula - as the dead body certainly cannot (under usual circumstances) engage in sexual intercourse (or wed), likewise Theodora should not be able to enjoy sexual intercourse with (or wed) anyone except the author. ${ }^{70}$

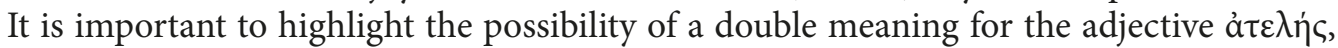
which, when applied to a corpse, could mean in addition to "useless" also "uninitiated", i.e. "buried without proper funeral rites". ${ }^{71}$ It was widely believed that "special dead" (to borrow David Garland's term), ${ }^{72}$ i.e. those who died prematurely, without proper burial rites, by their own hand, violently, or under other irregular circumstances, were uniquely positioned to facilitate magical operations. Another attestation of this belief provided by curse tablets has been identified only very recently (2018) by Jaime Curbera and Zinon Papakonstantinou in their new reading of a verso side of a legal curse from Athens, dated to the 3rd cent. BCE. In addition to a list of names written in a retrograde manner and a simile formula of the aversus subcategory on the recto side, the curse clearly turns towards the dead person in whose grave it was deposited.

a ghost. Regarding terminology and classification, see especially Felton 1999, 22-37 and Stramaglia 1999, 27-35. For the invocations of the dead in Greek magic, see Martín Hernández 2011, 100-111.

67 The tablet has usually been dated to the 4th century BCE; see, e.g., Gager 1992, 90, No. 22 or Graf 2005, 266, No. 89.

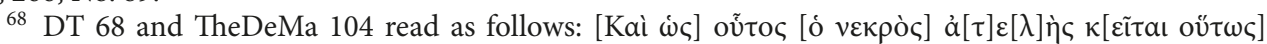

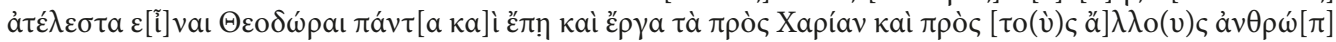
$\mathrm{o}(v) \varphi^{\cdot}$ ( "[And just as] this corpse lies useless, [so] may all the words and deeds of Theodora be useless with regard to Charias and to the other people", transl. Gager). We prefer the reading and interpretation proposed by Jordan 1993, 130, which we also print. A similar formula, unfortunately on a badly damaged tablet and

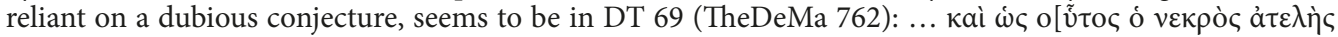

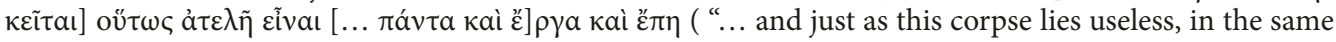
way useless may be [...] everything; both deeds and words", transl. Eidinow).

69 See Pachoumi 2013 for a recent overview of erotic and separation spells.

70 Cf. Petropoulos 1988, 220: “... it is undeniable that the defixio seeks to alienate a couple by mak-

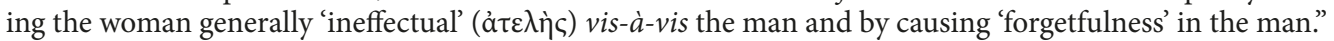

71 Jordan 1993, 130-131; the interpretation is also accepted by Johnston 1999, 78.

72 Garland 1985, 77-103. 
(18) Curbera - Papakonstantinou 2018, No. 3 (TheDeMa 955)

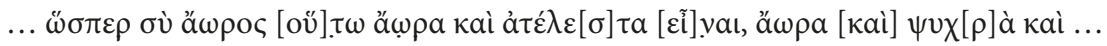

“...just as you are untimely dead, so let [the business of my opponents] be untimely and ineffective, untimely and cold and ..." CE. ${ }^{73}$

A similar analogy is also found in a curse from Pannonia, dated to the early 3rd cent.

(19) Gáspár 1990 (TheDeMa 350) ${ }^{74}$

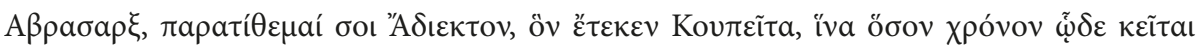

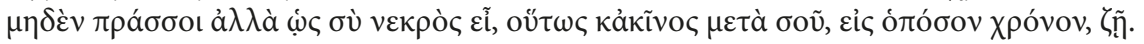

"Abrasarx (young flesh?), I deposit with you Adiektos, whom Koupeia bore, so that as long as [this dead body] lies here he will be unable to do anything, but just as you are dead, so let him be with you for his entire life."

Dorottya Gáspár, who published the editio princeps of the tablet, argued that the simile formula should be understood as "Just as you (scil. daemon) are dead, so should also he (scil. Adiektos) 'live' forever with you (scil. 'die')."75 This is largely correct, though we believe that it is not entirely clear whether the extension of the relative "you" is the corpse (which is trivially "dead") or the demon. As Gáspár herself noted, the appellative $\mathrm{A} \beta \rho \alpha \sigma \alpha \rho \xi$ (probably an alternative or misspelled form of $\mathrm{A} \beta \rho \alpha \sigma \alpha \xi$, well attested in all

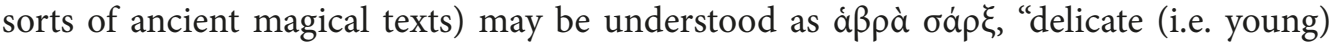

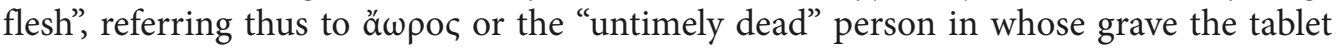

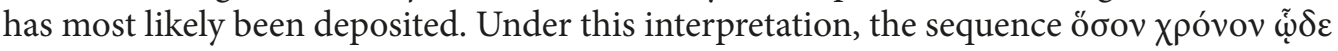

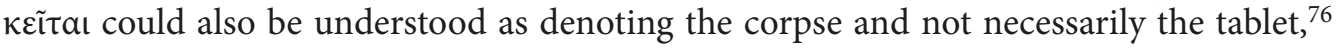
with the meaning of "for as long as this (corpse) lies here (= forever), let him be unable to do anything".

The following two Latin curses with simile formulae using a human corpse as the basis for a persuasive analogy exhibit strong parallelism to (17) and (18). Both are written in the context of a rivalry in love and function as separation spells - the women Philematio (20) and Rhodine (21), most likely slaves or freedwomen, are the objects of jealousy from another woman (or a man). Rhodine should be hated and scorned by M. Licinius (likely her master, maybe also lover?) and Philematio should be abandoned as well. Both are to become as attractive and pleasing to their masters and/or lovers as the corpses next to which the tablets have been deposited (both tablets were found in graves). The persuasive analogies are based on the parallel with the dead body that is separated from the living, unable to exercise any physical or mental action, and naturally arousing the emotion of disgust in human beings. The first curse (20), written on two tablets, comes from Pompei

73 NGCT 53.

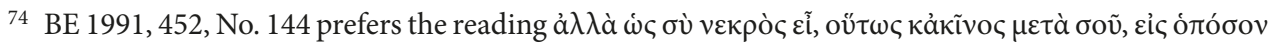

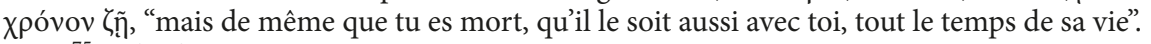

75 Gáspár 1990, 16.

76 This is how Gáspár 1990, 13 translated the text: "Abrasarx, ich übergebe dir den Adiektos, den Koupeita gebar, damit er, so lange (die Tafel) hier liegt, nichts tun kann, sondern wie du tot bist, so soll auch jener mit dir leben, für alle Zeit!" See also Barta 2015a, 133-134, with parallels to our item (21). 
and is dated to the 2 nd cent. CE; the second (21) was found in Rome and dates to the 1 st cent. BCE.

(20) DFX 1.5.4/1 (LCT 33, TheDeMa 543)

A: P(hi)lematio Hostili (serva) facia $(m)$ (=faciem) ... capil( $l) u(m)$, cerebru $(m)$, flatus, ren(es)...ut illai non suc(c)edat ${ }^{77} \ldots$ ut il(l)ic (=ille) illa(n)c (=illam) odiat. Como(do) ...(h)aec nec agere ne ilaic (=illa)... qui $(c) q u a(m)$ agere pos(s)it ula ...os $P($ hi)lematio... B: nec agere nec in...nec u(l)la(s) res pos(s)it pete(re), quae ul(l)o (h)uma(no)... Comodo (=quomodo) is eis desert(us), ilaec (=illa) deserta sit cu(n)no.

"Philematio, [the slave] of Hostilius: [I curse? her] face... hair, brain, breath, kidneys..., may she not succeed... may he hate her. Just like... this [corpse] cannot do anything... may she equally be unable to do anything... Philematio... may she be unable to act... or to ask for anything, what to any human (?) ... Just like this [corpse] is deserted by them, may she be deserted in her cunt." 78

(21) DT 139 (DFX 1.4.4/3, LCT 17, TheDeMa 263)

Quomodo mortuos, qui istic sepultus est nec loqui nec sermonare potest, seic Rhodine apud M(arcum) Licinium Faustum mortua sit nec loqui nec sermonare possit. Ita uti mortuos nec ad deos nec ad homines acceptus est, seic Rhodine apud M(arcum) Licinium accepta sit et tantum valeat, quantum ille mortuos, quei istic sepultus est. Dite pater, Rhodine(m) tibi commendo, uti semper odio sit M(arco) Licinio Fausto...

"Just like this dead one, who is buried here, cannot speak or talk [to anyone], so may Rhodine be dead for Marcus Licinius Faustus and not be able to speak or talk [to him]. Just like the dead one is dear to neither gods nor men, so may Rhodine be equally [little] dear to Marcus Licinius, and may she mean to him as much as this dead one who is buried here. Father Dis, I commend Rhodine to you so that she may always be hated by Marcus Licinius Faustus."

An interesting feature of some Greek and one Latin simile formulae is the explicit naming of the deceased in whose tomb the tablets have been deposited. At times, the dead person is even addressed directly in the 2 nd person singular and the vocative case. Consider, for instance, the "twin" curse-letter" directed to "Pasianax", found in Megara and dated variably between the 3 rd and 1 st cent. BCE. ${ }^{80}$ The two curses are virtually the same; the only thing that changes are the targets - in the first, the author seeks to incapacitate Neophanēs, and in the second Akestōr and Timandridas, all three being opponents in a legal battle.

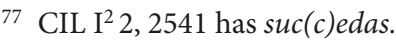

78 See also the interpretation of Varrone 2002, 128-129, who proposed the following as a possible context for the tablet: The curse was written by a women who is venting her anger at her rival, Philematio, slave of Hostilius, and - indirectly - also the man who evidently preferred this rival to her, reading the second simile as comodo is eis (=coleis) deser(tus)... ("Even as he must remain with idle testicles, so may she remain with an empty cunt...").

79 Regarding curse-letters, see further López Jimeno 1990 and Ceccarelli 2013, 47-53. We have already seen (12), where the curse tablet was called haec carta by the author.

${ }^{80}$ Ziebarth 1889, 126 dated it to the 2nd to 1st cent. BCE; Hoffmann 1900, 201 argued, pace Ziebarth, for the 3rd cent. BCE; a more recent entry in SEG 37:351/52 dated the two tablets to the 3rd cent. BCE. 
(22) SEG 37:351 (TheDeMa 139)

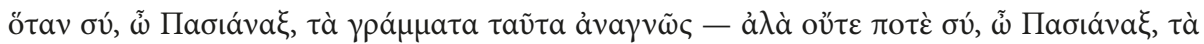

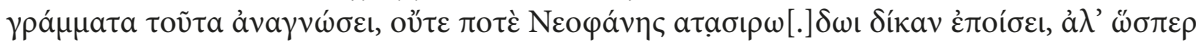

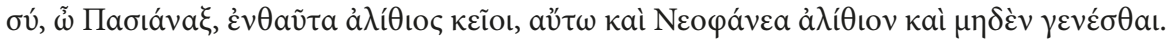

"Whenever you, O Pasianax, read this letter-but neither will you, O Pasianax, ever read this letter, nor will Neophanês ever direct a lawsuit against Aristandros (?). But just as you, O Pasianax, lie here idle, so also let Neophanês be idle and nothing." (transl. Gager)

(23) SEG 37:352 (TheDeMa 1202)

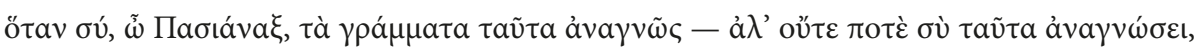

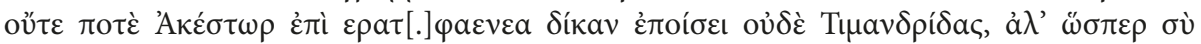

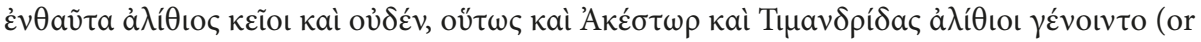
$\gamma \varepsilon v \varepsilon \dot{\sigma} \sigma \omega v)$.

"Whenever you, O Pasianax, read this letter-but neither will you ever read this (letter), nor will Akestôr direct a lawsuit against Eratophanês- and not Timandridas either. But just as you lie here idle and nothing, so also let Akestôr and Timandridas become idle." (transl. Gager)

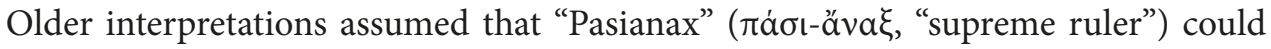
be an eponym for Hades, ${ }^{81}$ and argued that the author was invoking this infernal deity. These views have since been largely abandoned, ${ }^{82}$ and quite rightly so. John Gager argued (as Wünsch had long before him) ${ }^{83}$ that Pasianax is not a deity but the dead person buried in the grave in which the tablet has been deposited and the spell is based on a "curious set of assumptions" - the writer first assumes that the curse will be effective the moment Pasianax reads it ("whenever you read this letter"), but then realizes that corpses are quite unlikely to be able to read anything "but neither will you ever read this", and "thus the third and final thought takes the spell in an entirely new direction", using a simile formula as homeopathic magic that transfers the attributes of the corpse to the author's enemies at court. ${ }^{84}$

It seems highly unlikely to us that the writer could be so confused (especially since there are two almost identical curses!). Rather, it seems that the writer is constructing a persuasive analogy already with the first clause, albeit without the typical underlying syntax (a $\omega \sigma \pi \varepsilon \rho$... oü $\tau \omega \varsigma$ clause). We find it plausible that the meaning is something akin to "just as this corpse will never be able to read a letter, so let my enemies be unable to present a lawsuit.... It is very likely that this type of direct address to the deceased is found also on the tablet with similes already discussed as item (4). The other simile at the very beginning of the same tablet runs as follows.

(24) Curbera 2017, No. 2 (Ziebarth 1934, No. 23, TheDeMa 185)

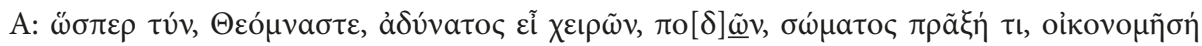

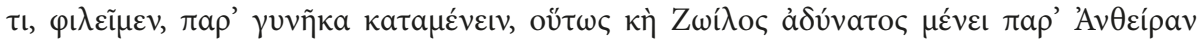

81 Wünsch 1900, 67: "Pasianax zunächst war offenbar ein alter Beiname des Königs der Unterwelt";

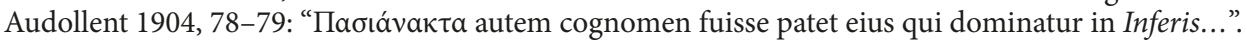

82 Dubois 1986, 321; Bravo 1987, 200.

83 Wünsch 1900, 67-68.

${ }^{84}$ Gager 1992, 130-131. 


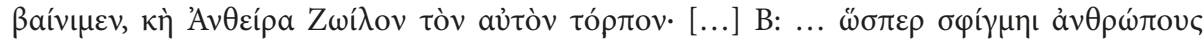

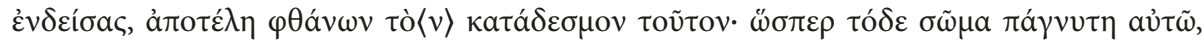

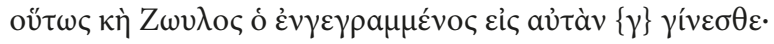

"Just as you, Theomnastos, are powerless in your hands, feet, body to do anything, to handle anything, to love, to stay with a woman, so too may Zoilos remain powerless to go to Antheira and in the same way Anthera (to go) to Zoilos [...] Just as you tie people up, hurry up and accomplish this binding-spell; just as this corpse here is stiff, so Zoilos, the one written here, should be towards her..." (transl. Curbera)

These similes, quite like (17) and (20), operate as separation formulae aimed at transferring the negative qualities of the dead corpse of Theomnēstos to Zōlios, the author's rival in love. One instance of a named dead individual is attested also with Latin defixiones. The tablet containing a curse in a legal context was found in a grave in Carthage and is dated to the 2 nd to 3 rd cent. CE:

(25) DT 221 (DFX 11.1.1/7, LCT 117, TheDeMa 794) $)^{85}$

...Se(curus?) como(d)o ...no(n) potes(t?) (contr)a nos d(e)r(e)spondere ... sic no(n possint respondere?) contra patre ( $m)$ meu ( $m$ con)tra (me) advocati ... comodo li(t)tera(e) non possu(nt) ... nec nemo potes $(t)$ ilos (=illoc) venire, comodo Securus ... o sic n (o)n pos(s)it (lo)qui, comodo Securus non potes(t?) loqui (sic $n$ )on possint (lo)qui arvo... (=advocati?)

"As Securus ... cannot testify against us..., so let the advocates be unable to testify against my father and me ... as the letter (= this tablet) ${ }^{86}$ is unable (scil. to leave this grave?) ... so let nobody be able to come (scil. to the court?) ... as Securus ... so let them be unable to speak, as Securus is unable to speak, so let the advocates be unable to speak ..."

Despite the less than optimal state of preservation, it seems clear to us that "Securus" is the corpse of the person in whose grave the tablet has been deposited and not the target of the curse (as Audollent would have it). ${ }^{87}$ The curse contains three simile formulae, of which two are readily interpretable. If we would accept nominative for vocative ${ }^{88}$ and the preserved form potes (2nd person singular), they could also read "Securus, just as you are unable to testify against us..." and "Securus, just as you are unable to speak...", but it makes little pragmatic difference. In both cases, the negative qualities of Securus (or, rather, his dead body) are to be transferred to the advocates and thus make them lose the legal battle they are waging against our author. Whether he addressed the dead body directly (potes) or indirectly (potest) is immaterial. The last Greek curse to be discussed under the rubric of the explicit naming of the dead people in whose graves tablets were deposited is an enigmatic early defixio from Sicily dated to the 5th cent. BCE and likely to be interpreted in a legal context, just as (23) and (25).

85 The emendations, only partially accepted, are those of Kropp (DFX 11.1.1/7); we follow Audollent's text for the most part.

${ }^{86}$ Other tablets also call curse tablets litterae (and even formally follow the norms of ancient letterwriting); see TheDeMa 769. For the term carta, see TheDeMa 575, 664, 713, 753, 1091.

87 DT 221.

${ }^{88}$ For the tendency to use the fixed nominative in curse texts, see Urbanová, in print. 
(26) Jordan - Rocca - Threatte 2014 (TheDeMa 945)

hōৎ "O

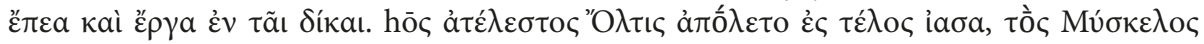

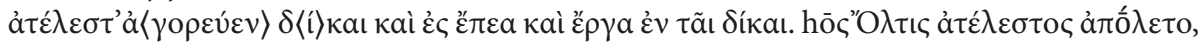

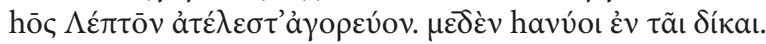

"As Oltis, being at/going to telos, was destroyed, so let Rhaton fruitlessly plead, him and Kelon/Kaikelon both in words and deeds in court. As, fruitless, Oltis was destroyed being at/going to telos, so let Myskelos fruitlessly < plead $>$ in court, both in words and deeds in court. As Oltis, fruitless, was destroyed, so let Lepton fruitlessly plead. Nothing be accomplished in court." (transl. Jordan - Rocca - Threatte)

The editors argued that the destruction of "Oltis", an otherwise unattested feminine

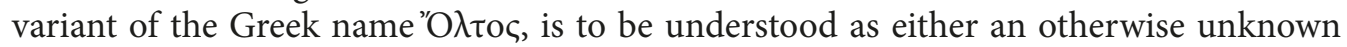
local historiola ${ }^{89}$ or a Plinian Olta, a wolf-like creature of Etruscan lore. ${ }^{90}$ We would like to suggest an alternative interpretation focused on the "fruitlessness" of "Oltis". The crux

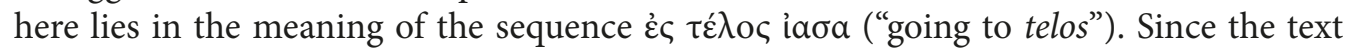

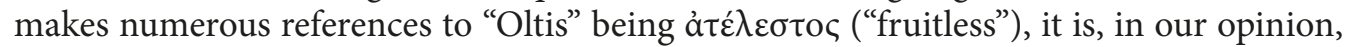
plausible to take the $\tau \dot{\varepsilon} \lambda$ oৎ to mean "proper burial" or "funerary rites". We have already

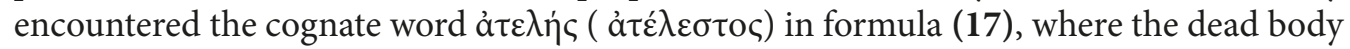
was referred to as "useless" or "lacking funeral rights". There are two more curses from Sicily that are relevant in this context: One from Lilybaion (Marsala, Sicily) in which

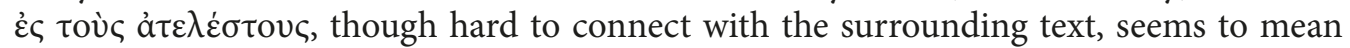
"to the ghosts of those lacking proper burial"; ${ }^{11}$ the other, a short defixio from the Buffa

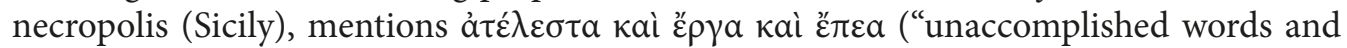
deeds"), ${ }^{92}$ mirroring almost verbatim our (26). Furthermore, we know from the Lex Sacra of Selinous, ${ }^{93}$ roughly contemporary with our tablet, that $\dot{\varepsilon} \lambda \alpha \sigma \tau \varepsilon$ é, spirits pursuing those who have committed a homicide, were believed to roam the land. In fact, it has been argued that one of the purposes of this "law" (in fact a purification procedure) was "to deal with comparable miasma arising from deaths and perhaps from ineffective funerary

89 See especially Rocca 2015, 307: “On peut aussi considérer la comparaison initiale comme une historiola à la saveur locale faisant référence à Oltis, personne que toute la ville connaît et dont lévocation du nom suffit à rappeler l'affaire en cours, une sorte de mini-récit qui donne peu d'informations, mais qui déploie la mémoire et les connaissances ainsi que la faculté du rédacteur d'adapter une situation particulière pour l'ériger en exemple parfait et, par extension, en norme générale".

90 Jordan - Rocca - Threatte 2014, 235, cf. Plin. NH 2, 240: Extat annalium memoria sacris quibusdam et precationibus vel cogi fulmina vel inpetrari. Vetus fama Etruriae est inpetratum, Volsinios urbem depopulatis agris subeunte monstro quod vocavere Oltam, evocatum a Porsina suo rege.

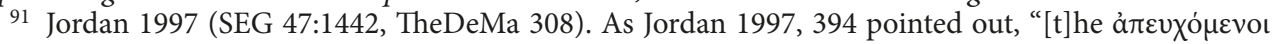

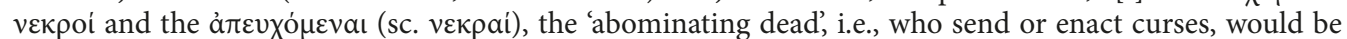

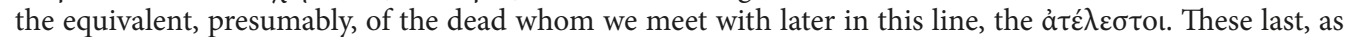
I would interpret them, are dead persons whose forces are still active because of a lack of proper funeral

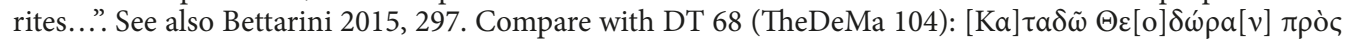

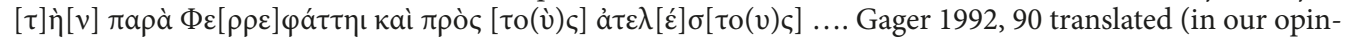
ion incorrectly) this as "I bind Theodora in the presence of the one (female) at Persephone's side and in the presence of those who are unmarried." The verso side of the tablet, on which simile (17) is found, makes it more probable that á $\dot{\varepsilon} \lambda \varepsilon \sigma \tau o$ here means "those dead people without proper funeral rites".

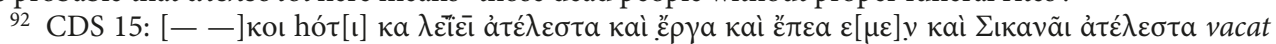

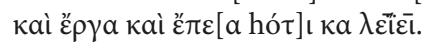

93 See Lupu 2009, 359-387, No. 27 for a recent edition, a translation, and commentary. 
rites for those dead ( $c f$. the miaroi Tritopatores) and to provide ritual cleansing from the pollution of hostile spirits, similar to those instigated by curse tablets". 94

Taken together with all the tablets discussed so far in this section, the phrase $\varepsilon \varsigma \tau \varepsilon \dot{\varepsilon} \lambda$ ○

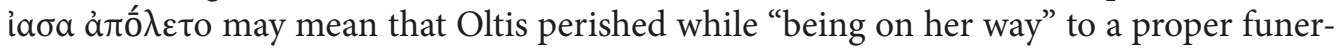

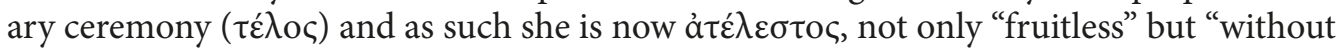
proper burial rites". Oltis then would be the name of the unfortunate female in whose grave the tablet was deposited, just like Pasianax, Theomnēstos, and Securus in our examples (22), (23), (24), and (25). The author chose her grave because she failed to find her

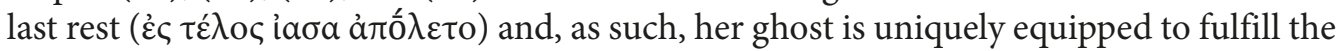
required magical transfer and cause the legal business of the author's adversaries to fail. It has already been acknowledged at the beginning of this section that a clear-cut differentiation between a dead body ( rather difficult to make. However, since similes (22) and (23) allude to Pasianax's inability to read a letter (i.e. a curse in the form of a letter) and simile (24) alludes to Theomnēstos' general inability to make a movement, it seems probable that the names "Pasianax" and "Theomnastos" denote the dead bodies of the men who once held these names rather than their ghosts. ${ }^{95}$ Let us now consider the following example from Olbia, dated variously to the 4 th or 3 rd cent. BCE. ${ }^{96}$

(27) Belousov, in print (Bravo 1987, SEG 37:673, Jordan 1997, TheDeMa 232)

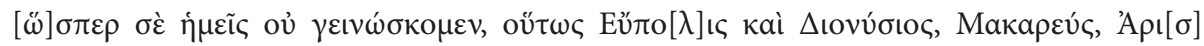

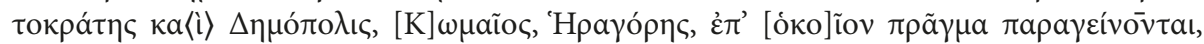

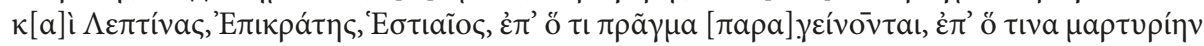

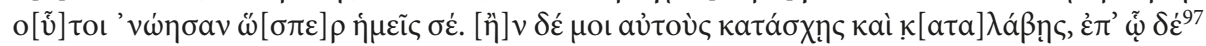

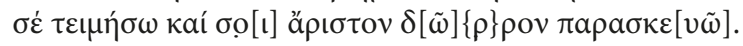

"Just as we do not know you, so shall not Eupolis and Dionysios, Makareus, Aristokrates and Demopolis, Komaios and Heragores [know us] at whichever lawsuit they attend. And also do not let Leptinas, Epikrates, Hestiaios attend any lawsuit for which they have planned (to give?) testimony - just as we do not know you. And if you maintain this spell on them

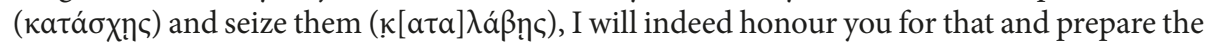
best gift." (transl. Belousov, modified)

On this defixio, which has been known for quite some time (editio princeps 1908) but garnered more attention following Benedetto Bravo's 1987 fresh reading and interpretation, ${ }^{98}$ the practitioners address the ghost, not the dead person's body. This is

94 Jordan 1993, 131. Regarding the relationship of the lex sacra to defixiones, see Bouffier 2015.

95 Already Bravo 1987, 198 highlighted the difference between "mort" in the sense of "lâme du mort" (= ghost of the dead) and in the sense of "une chose inerte, absolument impuissante" (= dead body). Du-

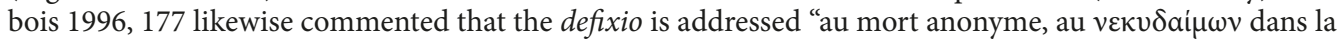
tombe duquel a été retrouvée la tablette et dont est implorée l'assistance efficace"; cf. also Nisoli 2007, 40-41.

96 Jordan 1997, 215 dated it to the 4th cent. BCE; Bravo 1987, 194 and Slings 1998, 85 to the 3rd cent. BCE; Belousov, in print, to the 4th-3rd cent. BCE.

${ }_{97}$ Nieto Izquierdo $2016,125-126$ proposed $\dot{\varepsilon} \pi \omega \delta<\tilde{\eta}>$ in lieu of $\dot{\varepsilon}\langle\gamma\rangle \grave{\omega} \delta \dot{\varepsilon}$, with the meaning "Si tu me les ligotes et les retiens avec une incantation, je te rendrai des honneurs".

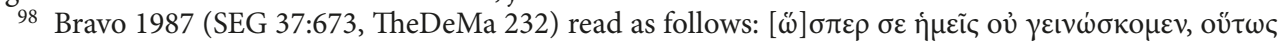

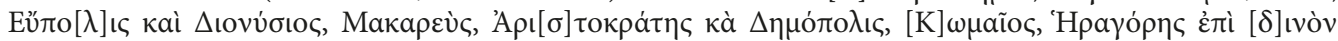

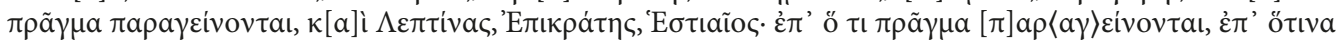

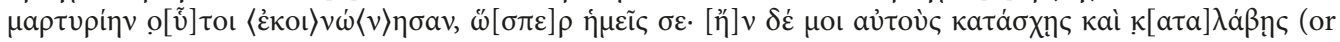


abundantly clear from the negotiation with the ghost in the concluding sentence, in which he is offered recompense should he succeed in paralysing the author's opponents in court. It would make little sense to be bargaining with a corpse. The tablet is also unique in that the $v \varepsilon \kappa v \delta \alpha i \mu \omega v$ does not act as an intermediary between the practitioner and the chthonic deities (nor is he commanded through chthonic deities with the typical katá injunction) but operates as an "autonomous entity" ${ }^{99}$ There are two outstanding issues here - first, the exact meaning of the simile formula itself, and second, the nature of the "most agreeable gift" that the practitioners are offering to the ghost.

Bravo argued that the simile served to reinforce the probability of an occurrence the practitioner had prior knowledge of, with a meaning akin to "as it is absolutely certain that I do not know you, ghost, let it be also certain that these men will come to the court and do a 'terrible thing' ( $\delta$ เvòv $\pi \rho \tilde{\alpha} \gamma \mu \alpha)$ ". ${ }^{100}$ It is unclear to us why the cursing party would want such a thing to happen given the fact that targets of judiciary curses are practically always enemies and the curses strive to incapacitate them before the court, not to make sure they make it there. Dubois mostly accepted Bravo's interpretation while noting that in formulae such as (22), (23), and (24) there is "un parallélisme de fond entre les deux membres du systéme comparatif; dans le texte d'Olbia ne subsiste plus que le cadre stylistique", ${ }^{101}$ which could be very much true but does not advance the interpretation of the simile in any way.

The reading proposed by David Jordan makes better sense in two ways: ${ }^{102}$ First, he argued that the second" $\Omega[\sigma \pi \varepsilon] \rho$ i $\mu \varepsilon \tilde{c}$ $\sigma \varepsilon$ ("just as we [do not know] you") is likely a mistake on the part of the author who was using a formulary, ${ }^{103}$ and second, it does away with the absurdity of the author wishing for his opponents to make it to the court and present evidence against him. Instead of the second “... just as we ...", we might imagine a forgotten second part of the clause with the meaning "... just as we do not know who you are, ghost, so too let Eupolis, Dionysos, and all the others ... at whatever lawsuit they are present ... at whatever taking of evidence ... let them [forget who we are and thus make it impossible for them to proceed against us?]". Second, according to Jordan, the ghost being "unknown" to the author means "buried without proper funeral rites" - and the "gift" consequently consists of paying proper tribute to the ghost and thus letting him rest. ${ }^{104}$

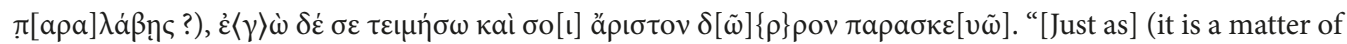
fact that) we do not know you, in the same manner (it is also true that) Eupolis and Dionusios, Makareos, Aristokratês and Dêmopolis, [K]ômaios, Heragorês are coming (to court) in order to do a terrible deed, and Leptinas, Epikratês, Hestiaios. (We do not know) for what deed they are coming (to court), (we do not know) upon what testimony those men have agreed, just as we do not know you. If you restrain and constrain them for me, I will honor you and prepare a most agreeable gift for you." (transl. Gager)

99 Bravo 1987, 211, see also Gager 1992, 138.

100 Bravo 1987, 195, followed by Nisoli 2007, 39-40.

101 Dubois 1996, 177.

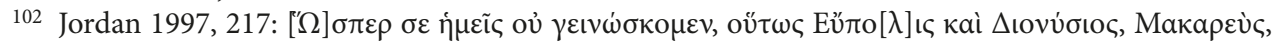

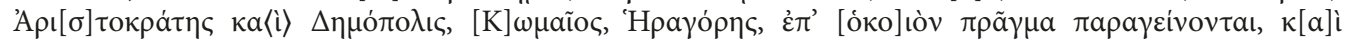

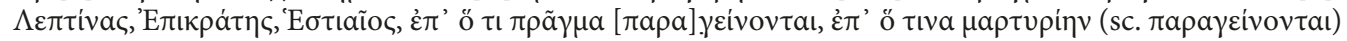

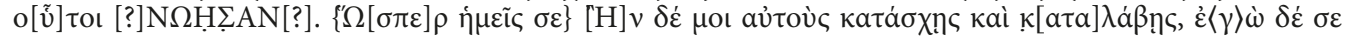

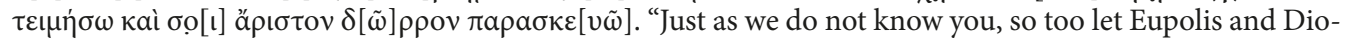
nysos, Makareus, Aristokrates and Demopolis, Komaios, Heragoras, at whatever lawsuit they are present, at

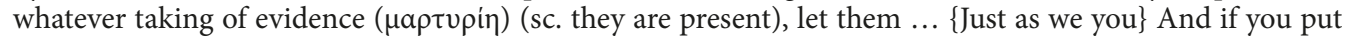
a spell on them and capture them, I shall indeed honor you and shall prepare for you the best of offerings." (transl. Jordan)

103 Jordan 1997, 216.

104 Jordan 1997, 217. 
The latest reading by Alexey Belousov further improves on Jordan's text and likewise argues that the curse is "a judicial spell addressed to a vengeful spirit ( $v \varepsilon \kappa v \delta \alpha i \mu \omega \nu)$ of an untimely deceased person (ä $\omega \rho \circ \varsigma)$ ". 105

This is an intriguing hypothesis, which in our opinion received further support in a remarkable defixio found in 2011 in the necropolis of ancient Pantikapaion (modern Crimea, reasonably close to Olbia Pontica/Borysthenes) and dated to the 3rd cent. BCE. ${ }^{106}$ This curse tablet contains a single word, à $v \omega \dot{v} v \mu$ o ( "without a name", i.e. "unknown"), repeated 18 times. The editors argued that this refers to "a special group of the dead called $\alpha \dot{\alpha} \omega \dot{v} v \mu \mathrm{ol}$, a group that includes the souls of people who died prematurely, usually in a violent manner", and cite our Olbian defixio as supportive evidence, concluding that "the addressee of the lead plate in question was the spirit of an untimely deceased person (or a number of such souls)". ${ }^{107}$ This agrees well with Jordan's and Belousov's interpretation as well as other items in our corpus, especially (5), (17), and (26). Another Greek curse that also features ghosts of the dead (as opposed to dead bodies) as the comparata in a simile formula is from a collection of over two dozen curses found at Amathous in Cyprus, dated to the 2 nd to 3 rd cent. CE. ${ }^{108}$ Its somewhat damaged text, the only one in the entire series containing a simile formula, reads as follows:

(28) Mitford 1971, No. 130 (TheDeMa 142)

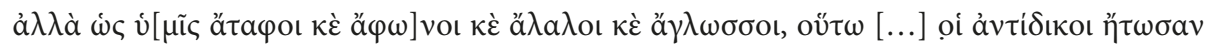

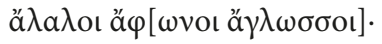

"But just as you are ... wordless and speechless ... so also let my opponents be speechless and voiceless." (transl. Gager)

The fact that the author of this curse is using ghosts of the dead as the basis of the persuasive analogy seems to be dictated by the incipit of the text, where he or she invoked "daimones whoever you may be and who lie here, having left grievous life, whether violent-

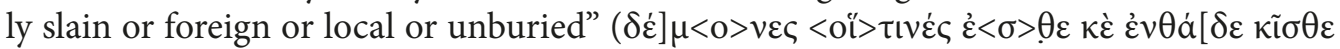

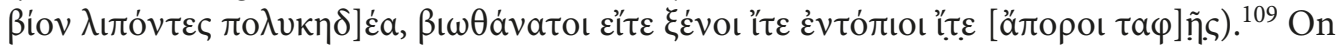

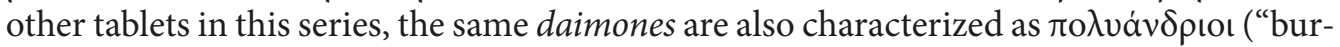

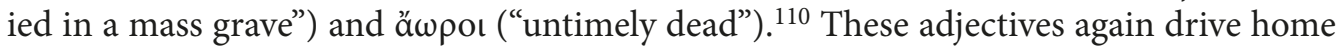
the importance of the "special dead" for magical practices, but some of these references, especially the passive "lying" and the unfortunate circumstances of the death ("untimely dead", "violently slain") and post-mortem irregularities ("buried in a mass grave", "unburied"), could be more easily associated with the inert physical bodies than with ghosts. Some degree of conflation between the two categories is to be expected, however, since corpses as objects are known to cause dissociation in our cognitive systems. ${ }^{111}$ Another

105 Belousov, in print.

106 Belousov - Fedoseev 2014.

107 Belousov - Fedoseev 2014, 147-148.

108 The provenance of this series of tablets has been indicated for a larger part of the 20th century incorrectly as Kourion; cf., e.g., Audollent 1904, 35; Preisendanz 1930, 131; and Mitford 1971. The original location has been identified by Aupert - Jordan 1981, 184.

109 The editorial supplements are reasonably safe since the formulaic text can be reconstructed on the basis of other, better preserved tablets in the Amathous series.

110 Mitford 1971, No. 127 (TheDeMa 141).

111 Boyer 2001, 203-228, especially 222-224. 
curse in a legal context containing a simile formula that mentions the ghosts or souls of dead people, albeit very obliquely, is attested from Attika and dated to the 4th cent. BCE.

(29) Robert 1936, No. 11 (TheDeMa 442)

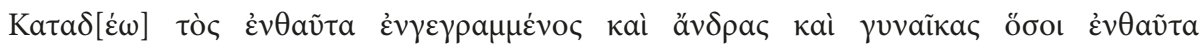

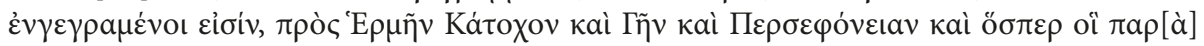

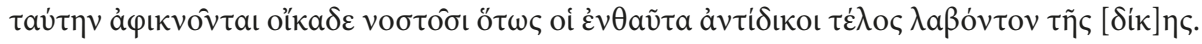

"I bind those inscribed here, both men and women who are here inscribed, in the presence of Hermès the Binder and Earth and Persephonē. And just as those who arrive at her side (scil. Persephone's) make a journey home, exactly in the same way may those opposing litigants reach the end of the lawsuit." (transl. Eidinow)

In this case, the writer does not seem to target restless ghosts who are $\beta \iota \omega \theta$ ávato

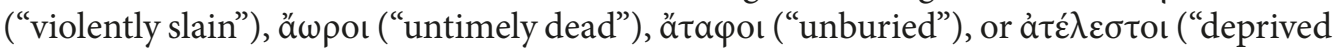
of proper funerary rites"), but rather the more peaceful lot whose death and burial did not exhibit any "irregularities" since they are making their last journey to the realm of Persephone (unlike the "restless" dead, to whom this last journey is forbidden). A Latin tablet from Rome, dated to the 4th-5th cent. CE, also seems to be addressed to a ghost. The author of this curse, which was found likely in a grave, ${ }^{112}$ appealed to "holy angels" (sancti angeli), but these are supposed to take his adversary into hell instead of the expected heaven. The curse is non-specific, possibly written in the context of a rivalry in love. The simile explicitly refers to the ghost being "trapped" in a tomb (anima intus inclusa):

(30) DFX 1.4.4/13 (LCT 25, TheDeMa 536)

Deprecor vos Sancti Angeli. Quomodo (ha)ec anima intus in(cl)usa tenetur et angustiatur (et) non vede(t) (ne)que (l)umine (=lumen), ne(que) a(li)quem (refri)gerium non (h)abet, (sic a-) nima, (mentes, cor)pos Collecticii, quem pepe(rit) Agne(lla) teneatur, ard(eat), destabescat (=detabescat). Usque (ad) infernum (se)mper (du)ci(t)e Collecticium, quem peperet Agnella. ${ }^{113}$

"I beg you, holy angels/daemons. Just like this soul is enclosed inside, imprisoned, and sees no light and has no recreation, so may the soul, mind, and body of Collecticius, whom Agnella bore, be equally enclosed, may it burn and fall into decay. Lead Collecticius, whom Agnella bore, away all the way to hell."

The last two items in this section have been published only recently by Andrea Barta. Both tablets are curses in a legal context found in graves in a necropolis at Acquincum, dated to the 2 nd to 3 rd cent. CE. ${ }^{114}$ The two curses are likely interrelated and (31) might help us with the interpretation of (32):

(31) Barta 2015a (TheDeMa 1115)

Dis Pater, Aeracura! Mercuri Cylleni, ea nomina tibi dicto, tradas diris canibus! Di Manes Tartaris! Marcum, Marciam, Charitonem, Secundum, quicumque adversarius surrexerit, qui

112 The exact location of the find is unknown. Solin 1968, 34 noted that the inscription, which is damaged to a large extent, was painted in black on the inner side of a terracotta urn.

113 Reading and emendations by A. Kropp.

114 Barta 2015a; Barta 2017a; see also Lassányi 2017 and Barta, in print. 
tibi antepistulam adferet. Muta et Tacita! Quomodo manes muti et taciti sunt, sic qui tibi antepistulam ${ }^{115}$ adferent, muti et taciti sint. Adversarios Bellici accipite, Tricerberi, et retinete ill $[-]$ os ... ${ }^{116}$

"Dis Pater, Aeracura! Mercurius Cyllenius, I dictate the following names to you, hand them over to the dreadful dogs! Infernal souls in Tartarus! Marcus, Marcia, Chariton, Secundus, and whoever may act like an opponent who will bring a curse-in-reply to you. Mute and Silent goddess! Just as the infernal souls are mute and silent, so are those who will bring a curse-in-reply to you may be mute and silent. Three-headed Cerberus, catch the opponents of Bellicus and keep them ..." (transl. Barta).

This curse is most likely a preventive anti-spell in case the author's enemies (probably in the context of a legal battle) would want to influence the case or harm him or her via a curse of their own. The desire to silence opponents is extremely common for Latin curses in legal contexts (see, e.g., 8, 25, etc.). Most relevant to our (31) is a tablet from Kempten (DFX 7.2/1, LCT 105) in which the infernal divinity Muta Tacita/ tacita ${ }^{117}$ is addressed by the author: Mutae tacitae, ut mutus sit Quartus, agitatus erret ut mus fugiens aut avis adversus basyliscum, ut e(i)us os mutu(m) sit, Mutae. Mutae (d)irae sint, Mutae, tacitae sint, mutae. ${ }^{118}(\mathrm{Qu}) a(r t) u s$ ut insaniat, ut Eriniis rutus sit et Quartus Orco. Ut Mutae tacitae, ut mut(ae s)int ad portas aureas. "Silent Mutae, [I ask you] may Quartus be mute, may he stray around aroused like a mouse, or a bird, fleeing from a basilisk, may his mouth be mute, Mutae. May Mutae be cruel, Mutae, may they be silent, mute. May Quartus go insane, may he be driven to Erinyes and [may] Quartus [be driven to] Orcus. May Mutae be silent, may they be mute at the golden gates." 119 Muta Tacita appears also on a Siscia tab$\operatorname{let}^{120}$ as a goddess that is supposed to silence the author's enemies (also in a legal context). The other Acquincum curse with a simile formula is significantly harder to interpret.

(32) Barta 2017a (TheDeMa 1429)

... Mercurio. At Tartara tradas comodo epistularius, qui tibi epistulas tradet ... epistula(s) tradet comodo verbis nar(r)at... sic atversari loquantor di manes contra Beroene $(m)$, contra $\operatorname{Iosimu}(\mathrm{m})$ (=Zosimum), qui tib(i) epistula(s) tradet, sic illos mutos (ta)c(i)tos (m)anes CRASSA vobis (ro)gamus...

115 Barta 2015a, 107 assumed that in the context of defixiones the word antepistula, unattested in Classical Latin (the only other known instance is attested in Greek from the 4th cent. CE with the meaning "letter in reply") is not a "letter in reply", but rather a "curse in reply", anticipating or knowing that the enemies of the defigens could or did try to curse her or him.

116 Emendations by Barta 2015a, 112.

117 The infernal goddess Tacita, probably an old Roman deity, is mentioned by Ovid in Fast. 2, 572, and her cult goes back to the age of the Roman Kingdom. Ovid (Fast. 2, 538) also refers to a nymph named Muta who was deprived by Jupiter of speech and condemned to live in the marshlands of the underworld because she slandered him. In addition, Ovid uses the word taciti to denote the underworld ghosts called Manes in his description of the festival of Lemuria (November 9 and May 13), which was the time when the ghosts of the deceased called lemures returned to their homes at night (Fast. 2, 422).

118 We assume that the author in this case invokes Mutae and uses tacitae as their epithet: Mutae (d) irae sint, Mutae tacitae sint, mutae.

119 Egger 1963, 254 associated the golden gate with Silius Italicus' gate to the underworld (Pun. 13, 556), which was golden as well. This would suggest that Mutae are supposed to guard this gate and deny Quartus entrance to Elysium.

120 Cf. a new revised reading with a helpful discussion of the previous interpretations by Barta 2017b, 28-38 and LCT 107. 
“... to Mercurius. As a messenger, hand over to Tartarus those who will hand letters to you ... will hand letters ... just as he/she does speak, so may our opponents speak, oh infernal souls, against Beroe and against Zosimus, who will hand letters to you, so the infernal souls may ... them mute and silence, we ask you." (transl. Barta)

The tablet is slightly damaged and the meaning of the two simile formulae is far from clear. ${ }^{121}$ The problem is the relative qui preceding epistulas tradet: Barta argued that it refers to either Mercury, who is asked to send to the underworld those who will hand him letters (curses), or someone unknown, most likely the nekydaimon, i.e. the spirit of the deceased person into whose grave the tablet was deposited, who is asked to send to Mercury in the underworld those who will hand letters (curses) to him. ${ }^{122}$ Given the Greek parallels in this section, the nekydaimon seems more probable. The simile quomodo verbis narrat might be adynaton (as with the Greek (22) and (23)), meaning something akin to "just as the ghost of the dead is unable to speak, so let also our enemies be unable to testify against Beroen". The next simile (in which quomodo is absent) could be interpreted as [quomodo] qui tibi epistulas tradet [mutus tacitus est], sic illos mutos tacitos (faciatis) di manes cras $^{123}$ a vobis rogamus. The basis of the persuasive analogy here might also be a ghost of the dead - the adjectives mutus and tacitus often refer to ghosts and are analogous to the Greek ä $\varphi \omega v o l$ kè ă $\lambda \alpha \lambda$ ol in (28) and the Latin manes in (31) (quomodo manes muti...). ${ }^{124}$

Summarizing conclusions as well as the remaining categories, namely (III) animals, (IV) historiolae and rituals, (V) aversus formulae and unusual orientations of the script, (VI) "names", and (VII) drawings, will be presented in a follow-up paper, to be published in the next issue of Philologia Classica.

$\begin{array}{ll}\text { Abbreviations } & \\ \text { BE } & \text { Bulletin épigraphique } \\ \text { CDS } & \text { Bettarini, Corpus delle defixiones di Selinunte } \\ \text { DFX } & \text { Kropp, Defixiones: Ein aktuelles corpus lateinischer Fluchtafeln } \\ \text { DT } & \text { Audollent, Defixionum Tabellae } \\ \text { DTA } & \text { Wünsch, Defixionum Tabellae Atticae } \\ \text { DTM } & \text { Blänsdorf, Defixionum Tabellae Mogontiacenses } \\ \text { LCT } & \text { Urbanová, Latin Curse Tablets of the Roman Empire } \\ \text { PGM } & \text { Preisendanz, Papyri Graecae Magicae } \\ \text { RIB } & \text { Roman Inscriptions of Britain } \\ \text { NGCT } & \text { Jordan, New Greek Curse Tablets } \\ \text { SGD } & \text { Jordan, A Survey of Greek Defixiones Not Included in the Special Corpora } \\ \text { SupplMag } & \text { Daniel - Maltomini, Supplementum Magicum }\end{array}$

121 The first line of side B, immediately before ...Mercurio..., is illegible. The text after ...tradet sic... containing the second part of the simile formula has been added vertically and runs through the rest of the text (probably due to the lack of space left on the tablet).

122 Barta, in print.

123 For a similar sequence, see Blänsdorf - Piranomonte 2012, 629: ...(roga)mus cras deas vest $($ ra $)$ s....

${ }^{124}$ Di Manes, the underworld ghosts, included also ghosts of people with untimely or violent deaths who roamed restlessly the places close to their bodies. For an overview of their powers with respect to the ancient cursing practices, see Audollent 1904, lix-lxvii; Preisendanz 1972, 6-8, 13, 17; Gager 1992, 12-16; Ogden 1999, 44-46; Kropp 2008b, 94-98. For a detailed survey on Di Manes in literature and epigraphy, see Tantimonaco 2016, 4-18. Her analysis suggests that, from the Augustan age onward, Manes are simply "defunti divinizzati". 
TabSulis

TheDeMa

ThesCRA
Tomlin, The Curse Tablets

Thesaurus Defixionum Magdeburgensis

Thesaurus Cultus et Rituum Antiquorum

\section{References}

Audollent A. Defixionum tabellae. Paris, Albert Fontemoing, 1904.

Aupert P., Jordan, D. R. Magical Inscriptions on Talc Tablets from Amathous. AJA 1981, 85 (2), 184.

Baratta G. Il piombo e la magia: Il rapporto tra l'oggetto e il materiale a proposito degli specchi plumbei, in: M. Piramonte, F. M. Simón (eds). Contesti magici - Contextos mágicos. Roma, De Luca Editori d’Arte, 2012, 23-27.

Baratta G. Bleierne Götter: Über aediculae mit mobilen Türflügeln. ACD 2013, 49 (1), 283-291.

Barta A. (a) Ito Pater, Eracura and the Messenger: A Preliminary Report on a New Curse Tablet from Aquincum. ACD 2015, 51, 101-113.

Barta A. (b) Római kori pannoniai átoktáblák és nyelvezetük (Szöveg, nyelv, funkció). Dissertation, Budapest, Eötvös Loránd University, 2015.

Barta A. (a) A Letter to the Underworld: A Research Report on the Curse Tablet Aq-2. AAntHung 2017, 57, $45-56$.

Barta A. (b) The Siscia Curse Tablet from a Linguistic Point of View: A New Autopsy. GLB 2017, 22 (2), $23-41$.

Barta A. (in print) Some Remarks on The Latin Curse Tablets from Pannonia, in: Proceedings of the 13th International Colloquium on Vulgar and Late Latin: Latin vulgaire - latin tardif XIII (Budapest, 2018) = AAntHung 2019, 59 .

Belousov, A. (in print) "Just Like We Do Not Know You": The New Edition of Olbian defixio IGDOP 109.

Belousov A., Fedoseev N. A New Magical Inscription from Panticapaeum's Necropolis. ZPE 2014, 190, $145-148$.

Bettarini L. Corpus delle defixiones di Selinunte: Edizione e commento. Alessandria: Edizioni dell'Orso 2005.

Bettarini L. Selinunte tra madrepatria e mondo coloniale: La testimonianza della lingua delle defixiones, in: A. Iannucci, F. Muccioli, M.Zaccarini (eds). La città inquieta: Selinunte tra lex sacra $e$ defixiones. Milano - Udine, Mimesis Edizioni, 2015, 285-298.

Blänsdorf J. So verfluchten die alten Römer, in: Chronik: Schuljahr 2007/2008. Speyer, Gymnasium am Kaiserdom 2007-2008, 6-23.

Blänsdorf J. Die defixionum tabellae des Mainzer Isis- und Mater Magna-Heiligtums: Defixionum tabellae Mogontiacenses. Mainz: Generaldirektion Kulturelles Erbe Rheinland-Pfalz, Direktion Landes-archäologie Mainz, 2012.

Blänsdorf J., Piranomonte M. Schede di catalogo IX, 49.3-6., IX, 49.8-28, in: R. Friggeri, M. G. Granino Cecere, G. L. Gregori (eds). Terme di Diocleziano: La collezione epigrafica. Milano, Electa, 2012, 617-639.

Bouffier S. La lex sacra: Une loi contre la malédicion?, in: A. Iannucci, F. Muccioli, M.Zaccarini (eds). La città inquieta: Selinunte tra lex sacra e defixiones. Milano - Udine: Mimesis Edizioni, 2015, 241-260.

Boyer P. Religion Explained: The Evolutionary Origins of Religious Thought. New York: Basic Books, 2001.

Bravo B. Une tablette magique d'Olbia Pontique: Les morts, les héros et les démons, in: M. Détienne, N. Loraux, C. Mossé, P. Vidal-Naquet (eds). Poikilia: Études offertes à Jean-Pierre Vernant. Paris, Éditions de l'École des Hautes Études en Sciences Sociales, 1987, 185-218.

Ceccarelli P. Ancient Greek Letter Writing: A Cultural History (600 BC - 150 BC). Oxford, OUP, 2013.

Curbera, J. Six Boeotian Curse Tablets. ZPE 2017, 204, 141-158.

Curbera J., Papakonstantinou, Z. Six Legal Curse Tablets from Athens, in: W. Riess (ed.) Colloquia Attica: Neuere Forschungen zur Archaik, zum athenischen Recht und zur Magie. Stuttgart, Steiner, 2018, 211-224.

Daniel R. W., Maltomini F. Supplementum Magicum, Vol. II. Opladen, Westdeutscher Verlag, 1992.

Dreher, M. Gerichtsverfahren vor den Göttern? "Judicial Prayers" und die Kategorisierung der defixionum tabellae, in: G. Thür (ed.) Symposion: Voträge zur griechischen und hellenistischen Rechtsgeschichte, Seggau 25. - 30. 8. 2009. Wien, Verlag der Österreichischen Akademie der Wissenschaften, 2010, 301-335.

Dreher, M. "Prayers for Justice" and the Categorization of Curse Tablets, in: M. Piranomonte, F. M. Simón (eds). Contesti magici - Contextos mágicos. Roma, De Luca Editori d’Arte, 2012, 29-32.

Dubois L. Recherches sur le dialecte arcadien, Vol. II: Corpus dialectal. Louvain-la-Neuve, Cabay, 1986.

Dubois L. Inscriptions grecques dialectales de Sicilie: Contribution à létude du vocabulaire grec colonial. Rome, École Française de Rome, 1989. 
Dubois L. Inscriptions grecques dialectales d'Olbia du Pont. Genève, Libraire Droz, 1996.

Egger R. Eine Fluchtafel aus Carnuntum, in: A. Betz, G. Moro (eds). Römische Antike und frühes Christentum: Ausgewählte Schriften von R. Egger, Band I. Klagenfurt, Verlag des Geschichtsvereins für Kärnten, 1962, 81-97.

Egger R. Liebeszauber, in: A. Betz, G. Moro (eds). Römische Antike und frühes Christentum: Ausgewählte Schriften von R. Egger, Band II. Klagenfurt, Verlag des Geschichtsvereins für Kärnten, 1963, 24-33.

Eidinow E. Oracles, Curses, and Risk among the Ancient Greeks. Oxford, OUP, 2007.

Faraone C. A. Hermes but No Marrow: Another Look at a Puzzling Magical Spell. ZPE 1988, 72, 279-286.

Faraone C. A. The Agonistic Context of Early Greek Binding Spells, in: C. A. Faraone, D. Obbink (eds). Magica Hiera: Ancient Greek Magic and Religion. New York - Oxford, OUP, 1991, 3-32.

Faraone C. A. Ancient Greek Love Magic. Cambridge, Mass. — London, Harvard UP, 1999.

Felton D. Haunted Greece and Rome: Ghost Stories from Classical Antiquity. Austin, University of Texas Press, 1999.

Forbes R. J. Metallurgy in Antiquity: A Notebook for Archaeologists and Technologists. Leiden, Brill, 1950.

Frazer J. G. The Golden Bough: A Study in Magic and Religion. London, Macmillan, 1990.

Frei-Stolba R., Koch P., Lieb H. W. Eine neue Fluchtafel aus Kempraten (Kt. St. Gallen/CH), in: M. Scholz, M. Horster (eds). Lesen und schreiben in den Römischen Provinzen: Schriftliche Kommunikation im Alltagsleben. Mainz, Verlag des Römisch-Germanischen Zentralmuseums, 2015, 113-122.

Gager J. G. Curse Tablets and Binding Spells form the Ancient World. New York - Oxford, OUP, 1992.

Garland R. The Greek Way of Death. Ithaca (NY), Cornell UP, 1985.

Gáspár D. Eine griechische Fluchtafel aus Savaria. Tyche 1990, 5 (1), 13-16.

Geisseler P., Koch P. Diebstahl am Zürichsee: Eine Fluchtafel aus dem Magna Mater-Heiligtum in Kempraten (Kt. St. Gallen, Schweiz). ZPE 2018, 207, 298-307.

Giangrande G. Hermes and the Marrow: A Papyrus Love-Spell. AncSoc 1978, 9 (1), 101-116.

Gorissen P. Once More the Love-Spell of Hermes and the Marrow. ZPE 1980, 37, 199-200.

Graf F. Gottesnähe und Schadenzauber: Die Magie in der griechisch-römischen Antike. München, Beck, 1996.

Graf F. Fluch und Verwünschung. ThesCRA 2005, 3, 247-270.

Griffiths J. G. Hermes and the Marrow in a Love-Charm. ZPE 1977, 26, 287-288.

Hoffmann O. Zwei neue arkadische Inschriften. Philologus 1900, 59 (1), 201-205.

Johnston S. I. Restless Dead: Encounters Between the Living and the Dead in Ancient Greece. Berkeley — Los Angeles - London, University of California Press, 1999.

Jordan D. R. (a) A Survey of Greek Defixiones Not Included in the Special Corpora. GRBS 1985, 26 (2), 151-197.

Jordan D. R. (b) Defixiones from a Well Near the Southwest Corner of the Athenian Agora. Hesperia 1985, 54 (3), 205-255.

Jordan D. R. Curse Tablets at Selinous, in: M.H. Jameson, D. R. Jordan, R. D. Kotansky (eds). A Lex Sacra from Selinous. Durham (NC), Duke University, 1993, 125-131.

Jordan D. R. An Address to a Ghost at Olbia. Mnemosyne 1997, 50 (2), 212-219.

Jordan D. R. New Greek Curse Tablets (1985-2000). GRBS 2000, 41 (1), 5-46.

Jordan D. R. An Opisthographic Lead Tablet from Sicily with a Financial Document and a Curse Concerning Choregoi, in: P. Wilson (ed.) The Greek Theatre and Festivals: Documentary Studies. Oxford, OUP, 2007, 335-350.

Jordan D. R., Rocca G., Threatte L. Una nuova defixio dalla Sicilia (Schøyen Collection MS 1700). ZPE 2014, $188,231-236$.

Kagarow E. G. Griechische Fluchtafeln. Leopoli, Editum auxilio ministerii instructionis publicae, 1929 (Eus Supplementa Vol.4).

Kropp A. 'Defigo Eudemum: necetis eum': Kommunikationsmuster in den Texten antiker Schadenzauberrituale, in: K. Brodersen, A. Kropp (eds). Fluchtafeln: Neue Funde und neue Deutungen zum antiken Schadenzauber. Frankfurt am Main, Verlag Antike, 2004, 81-97.

Kropp A. (a) Defixiones: Ein aktuelles Corpus lateinischer Fluchtafeln. Speyer, Kartoffeldruck-Verlag Kai Brodersen, 2008.

Kropp A. (b) Magische Sprachverwendung in Vulgärlateinischen Fluchtafeln (defixiones). Tübingen, Gunter Narr Verlag, 2008.

Kropp A. How does Magical Language Work? The Spells and Formulae of the Latin Defixionum Tabellae, in: R.L.Gordon, F. M. Simón (eds). Magical Practice in the Latin West: Papers from the International Conference held at the University of Zaragoza, 30th Sept. - 1st Oct. 2005. Leiden, Brill, 2010, 357-380. 
Kropp A. „... Dann trag das Bleitäfelchen weg ans Grab eines vorzeitig Verstorbenen“: Antike Fluchtafeln als Textträger und Ritualobjekte, in: A. Kehnel - D. Panagiotopoulos (eds). Schriftträger - Textträger: Zur materialen Präsenz des Geschriebenen in frühen Gesellschaften. Berlin, Walter de Gruyter, 2015, 73-101.

Lassányi G. (ed.) On Secret Paths: Dark Spells in Aquincum. Budapest, Budapest History Museum, 2017.

Lejeune M. En marge de la défixion de Montfo. CRAI 1981, 125 (1), 51-52.

López Jimeno A. Las cartas de maldición. Minerva 1990, 4 (1), 131-143.

López Jimeno A. Textos griegos de maleficio. Madrid, Akal, 2001.

Lupu E. Greek Sacred Law: A Collection of New Documents. Leiden - Boston, Brill, ${ }^{2} 2009$.

Nemeroff C., Rozin P. The Makings of the Magical Mind: The Nature and Function of Sympathetic Magical Thinking, in: K. S. Rosengren, C. N. Johnson, P. L. Harris (eds). Imagining the Impossible: Magical, Scientific, and Religious Thinking in Children. Cambridge: CUP, 2000, 1-34.

Marichal R. Une tablette d'exécration de l'oppidum de Montfo (Hérault). CRAI 1981, 125 (1), 41-51.

Martín Hernández, R. Invocaciones a los muertos en los textos griegos mágicos, in: R. Martín Hernández, S. Torallas Tovar (eds). Conversaciones con la muerte: Diálogos del hombre con el Más Allá desde la Antigüedad hasta la Edad Media, Madrid, Consejo Superior de Investigaciones Científicas 2011.

Miller A. P. Studies in Early Sicilian Epigraphy: An Opistographic Lead Tablet. Dissertation, Chapel Hill (NC), University of North Carolina at Chapel Hill, 1973.

Mitford T. B. The Inscriptions of Kourion. Philadelphia, American Philosophical Society, 1971.

Nieto Izquierdo E. Note de lecture sur la defixio SEG 47, 1191.1 (Olbia du Pont). Mnemosyne 2016, 69 (1), 123-127.

Nisoli A. G. Parole segrete: Le "defixiones". Acme 2007, 60 (3), 36-46.

Ogden D. Binding Spells: Curse Tablets and Voodoo Dolls in the Greek and Roman Worlds, in: B. Ankarloo, S. Clark (eds). Witchcraft and Magic in Europe, Vol.2: Ancient Greece and Rome. London, Athlone Press, 1999, 1-90.

Pachoumi E. The Erotic and Separation Spells of the Magical Papyri and Defixiones. GRBS 2013, 53 (2), 294-325.

Petropoulos J. C. B. The Erotic Magical Papyri, in: B. G. Mandilaras (ed.) Proceedings of the XVIII International Congress of Papyrology, Athens 25-31 May 1986. Athens, Greek Papyrological Society, 1988, 215-222.

Preisendanz K. Die griechischen und lateinischen Zaubertafeln. APF 1930, 9 (1-2), 119-154.

Preisendanz K. "Fluchtafel", in: Reallexikon für Antike und Christentum, 1972, Vol. VIII, 1-29.

Pyysiäinen I. Magic, Miracles, and Religion: A Scientist's Perspective. Lanham (MD), AltaMira Press, 2004.

Ready J.L. The Homeric Simile in Comparative Perspectives: Oral Traditions from Saudi Arabia to Indonesia. Oxford, OUP, 2018.

Robert L. Collection Froehner, Vol. I: Inscriptions grecques. Paris, Éditions des Bibliothèques Nationales, 1936.

Rocca G. Les defixiones siciliennes: aspects publics et privés, in: E. Dupraz, W. Sowa (eds). Genres épigraphiques et langues d’attestation fragmentaire dans l'espace méditerranéen. Mont-Saint-Aignan, Presses universitaires de Rouen et du Havre, 2015, 305-313.

Rocca, G., Bettarini, L., Bevilacqua, G. (in print) Basilisa kyria: Una defixio siciliana inedita.

Russell P. Vilbiam (RIB 154): Kidnap or Robbery? Britannia 2006, 37, 363-367.

Scott W. C. The Oral Nature of the Homeric Simile. Leiden, Brill, 1974.

Scott W. C. The Artistry of the Homeric Simile. Hanover (NH) - London, UP of New England, 2009.

Slings S. R. $\delta \dot{\varepsilon}$ or $\delta \dot{\eta}$ in a defixio from Olbia? Mnemosyne 1998, 51 (1), 84-85.

Solin H. Eine neue Fluchtafel aus Ostia. Commentationes humanarum litterarum, Societas scientiarum Fennica 1968, 42, 3-31.

Sørensen J. A Cognitive Theory of Magic. Lanham (MD), AltaMira Press, 2007.

Stanco E. A. Quintus Agrippini servus e la villa (degli Avidii?) in località Fontanaccia: A proposito di una nuova defixio latina dai monti della Tolfa. BCAR 2003, 104, 127-144.

Stramaglia A. Res inauditae, incredulae: Storie di fantasmi nel mondo greco-latino. Bari, Levante Editori, 1999.

Tantimonaco S. Stant Manibus Arae: I manes nell' Eneide di Virgilio. Annuari de Filologia: Antiqua et Mediaevalia 2016, 6, 1-21.

Tambiah S. Form und Bedeutung magischer Akte, in: H. G. Kippenberg, B. Luchesi (eds). Magie: Die sozialwissenschaftliche Kontroverse über das Verstehen fremden Denkens. Frankfurt am Main, Suhrkamp, 1978, 259-296. 
Tomlin R. S. O. The Curse Tablets, in: B. Cunliffe (ed.) The Temple of Sulis Minerva at Bath, Vol II: Finds from the Sacred Spring. Oxford, Oxford University Committee for Archaeology, 1988, 59-277.

Tomlin R. S. O., Hassall M. W. C. II. Inscriptions. Britannia 1999, 30, 375-386.

Tremel J. Magica agonistica: Fluchtafeln im antiken Sport. Hildesheim: Weidmann, 2004.

Turner E. G. The Marrow of Hermes, in: F. Bossier, F. de Wachter, G. Maertens et al. (eds). Images of Man in Ancient and Medieval Thought: Studia Gerardo Verbeke ab amicis et collegis dictate. Leuven, Leuven UP, 1976, 169-173.

Tylor E. B. Primitive Culture: Researches into the Development of Mythology, Philosophy, Religion, Art, and Custom. London, John Murray, 1871.

Urbanová, D. Die lateinischen tabellae defixionum: Der Usus und die Spezifika am Gebiet des römischen Reiches, in: P. Molinelli, P. Cuzzolin, Ch. Fedriani (eds). Latin vulgaire - Latin tardif X: Actes du Xe colloque international sur le latin vulgaire et tardif, Bergamo 2012. Bergamo, Bergamo UP, 2014, 10471098.

Urbanová D. Alcune particolarità della comparazione (quomodo - sic, quemadmodum - sic, ita uti - sic) in latino volgare, con particolare attenzione alle defixiones. GLB 2016, 21 (2), 329-343.

Urbanová D. The Latin Curse Tablets of the Roman Empire. Innsbruck, Institut für Sprachen und Literaturen der Universität Innsbruck, 2018.

Urbanová D. (in print) Between Syntax and Magic: Some Peculiarities of Nominal Syntax in Latin Curse Tablets, in: 19th International Colloquium on Latin Linguistics, April 24-28 2017, Munich.

Varrone A. Erotica Pompeiana: Love Inscriptions of the Walls of Pompei. Roma, L'Erma di Bretschneider, 2002.

Versnel H. S. A Twisted Hermes: Another View of an Enigmatic Spell. ZPE 1988, 72, 287-292.

Versnel H.S. Beyond Cursing: The Appeal to Justice in Judicial Prayers, in: C. A. Faraone, D. Obbink (eds). Magika Hiera: Ancient Greek Magic and Religion. Oxford, Oxford University Press, 1991, 60-106.

Versnel H. S. Prayers for Justice in East and West: Recent Finds and Publications, in: R. L. Gordon, F. M. Simón (eds). Magical Practice in the Latin West: Papers from the International Conference held at the University of Zaragoza, 30th Sept. - 1st Oct. 2005. Leiden, Brill, 2010, 275-356.

Wilson P. Sicilian Choruses, in: P. Wilson (ed.) The Greek Theatre and Festivals: Documentary Studies. Oxford, OUP, 2007, 351-377.

Wünsch R. Defixionum tabellae atticae. Berlin, Apud Georgium Reimerum, 1897.

Wünsch R. Neue Fluchtafeln. RhM 1900, 55 (1), 62-85.

Yelle R. A. Rhetorics of Law and Ritual: A Semiotic Comparison of the Law of Talion and Sympathetic Magic. JAAR 2001, 69 (3), 627-647.

Ziebarth E. Neue attische Fluchtafeln. Nachrichten der K. Gesellschaft der Wissenschaften zu Göttingen, Philologisch-historische Klasse 1899, 2, 105-133.

Ziebarth E. Neue Verfluchungstafeln aus Attika, Boiotien und Euboia. Sonderausgabe aus den Sitzungsberichten der Preussischen Akademie der Wissenschaften, Philologisch-historische Klasse 1934, 33, 1022-1050.

Received: February 9, 2019

Accepted: April 6, 2019 